\title{
Okul öncesi öğretmen adaylarının bebeklik döneminde kurum temelli eğitime ilişkin görüşleri
}

\section{Pre-service early childhood educators' point of views regarding center - based infant-toodler education}

\begin{abstract}
Şenil Ünlü Çetin ${ }^{1}$
Makale Geçmişi

Geliş : $\quad 31$ Mart 2019

Düzeltme : 19 Mayıs 2019

Kabul : 25 Mayıs 2019

Çevrimiçi : 02 Temmuz 2019

Makale Türü

Arastrma Makalesi

Öz: Okul öncesi eğitim doğumdan başlayan ve temel eğitimin başlamasına kadar devam eden bir eğitim sürecidir. Türkiye'de ise kamu alanında çalışan okul öncesi öğretmenleri çoğunlukla 36-72 aylık çocuklarla çalışmakta, öğretmen yetiștirme programları da öğretmen adaylarını daha çok bu yaş grubu ile çalışmaya hazırlamaktadır. 0-36 aylık çocuklara eğitim veren kurumlarda çalışması öncelikli gruplardan biri de okul öncesi ögrretmenliğinden mezun olan bireylerdir. Ancak ilgili alan yazını, okul öncesi öğretmen ve öğretmen adaylarının bu kurumlarda çalışmaya yönelik ne düşündüğüne dair neredeyse hiçbir bilgi sunmamaktadır. Mevcut araştırmanın amacı okul öncesi öğretmen adaylarının bebeklik döneminde kurum temelli eğitime yönelik görüşlerini betimlemek ve bu görüşlerin farklı ylllarda son sınıfta okuyan öğretmen adayları arasında değişip değişmediğini ortaya koymaktır. Bu amaç doğrultusunda çalışmanın verileri farklı yıllarda okul öncesi öğretmenliği programının son sınıfinda okuyan 120 öğretmen adayından yazılı görüşme formu aracılı̆̆ı ile toplanmıştır. Veriler nitel içerik analizi metodu ile analiz edilmiștir. Bulgular öğretmen yetiștirme programları, genel uygulamalar ve sosyal politikalar bağlamında eleştirel bir gözle tartışılmıştır.
\end{abstract}

\section{Article History}

Received : 31 March 2019

Revised : 19 May 2019

Accepted : 25 May 2019

Online : 02 July 2019

Article Type

Research Article
Anahtar Kelimeler: Bebeklik döneminde eğitim; Okul öncesi öğretmen adayları; 0-36 aylık bebeklerin bakım ve eğitimi

\begin{abstract}
Early childhood education refers to the education services provided to children between the ages of zero and the age of formal schooling. In Turkey, public pre-schools provide educational services for children between the ages of 36-69 months; therefore, early childhood teacher education programs mostly prepare their students for working with 36-69 months of children. Nevertheless, early childhood educators are one of the primary groups who can work in the early childhood care and education centers that provide services for $0-36$ months of age children, as well. In the national literature there is a gap regarding how in-service and pre-service early childhood educators think about working with infants and toddlers. Therefore, the main aim of the current study is to understand the point of view of preservice early childhood educators regarding center based infant-toddler education and working with infants. Additionally, in the current study it is aimed to examine whether perceptions related to infant toddler education have changed among pre-service early childhood educators who are in the fourth grade of their undergraduate education at different years. Therefore, the data of the study was gathered from 120 pre-service early childhood educators who are at their fourth grade in different years. Writteninterview protocol including five open-ended questions was used to gather data in each year. Thematic analysis was used as the data analysis technique. Findings are critically discussed based on the teacher education program, general applications and social policies.
\end{abstract}

Keywords: Infant-toddler education; Pre-service early childhood educators; Education and care of 036 months of age children

\footnotetext{
${ }^{1}$ Kırkkkale Üniversitesi, Eğitim Fakültesi, Okul Öncesi Eğitimi ABD e-mail:senilunlucetin@gmail.com, ORCID: https://orcid.org/0000-0001$\underline{9898-1609}$
}

\footnotetext{
Atıf için/To cite this article:

Ünlü Çetin, S. (2019). Okul öncesi öğretmen adavlarının bebeklik döneminde kurum temelli eğitime ilișkin görüșleri. Erken Cocukluk Calssmalar Dergisi, 3(2), 300-333. doi:http://dx.doi.org/10.24130/eccd-jecs.1967201932138
} 


\section{SUMMARY}

\section{Introduction}

In Turkey, early childhood education begins with the birth of the child and it continues up to the time that the child begins formal education. Within this context, early childhood teachers should be qualified to work with children from birth to 69 months of age when they graduated from the teacher education program. However, in Turkey, early childhood educators are working with 36-69 months old children in public early childhood education centers and therefore, early childhood teacher education programs mostly provide theoretical information and practical opportunities for candidate early childhood educators to work with this age group. According to the Legislation of Ministry of Family and Social Policies, early childhood educators are included in the primary groups who can work in crèches and day care centers that provide education and care services for children under three, as a founding manager, manager or group leader. Unfortunately, there is almost no study indicated what in-service or pre-service early childhood educators think about working with younger children in their professional lives. This qualitative description study aims to examine pre-service early childhood educators' opinions about center based infant-toddler education. The second main aim of the study is to understand whether these opinions have changed among preservice early childhood educators who are fourth grade students in different years. In the light of this aim, following research questions were guided this research,

I. What are the opinions of pre-service early childhood educators related to center based infant-toddler education?

a. What are the opinions of pre-service early childhood educators related to the importance of infancy and toddlerhood period?

b. What are the opinions of pre-service early childhood educators related to the center based infancy and toddlerhood education?

c. What are the opinions of pre-service early childhood educators related to the working with infants and toddlers?

II. Have the opinions related to infant toddler education changed among pre-service early childhood educators' who were at fourth grade of their undergraduate education in different years?

\section{Method}

The research design of the current study is qualitative description. Qualitative description rsearch based on natural inquiry and mainly aims to describe participants' ideas with minimum interpretation (Sandelowski, 2000). Typical case sampling, which aims to include participants who has average characteristics related to phenomenon (Miles ve Huberman, 1994), is the purposive sampling technique used in this study. Participants were 120 pre-service early childhood educators who were the fourth grade students in 2008 $(n=20), 2010(n=25), 2012(n=35), 2014(n=24)$ and $2015(n=15) .110$ of the participants were female while remaining 10 were male students with the average age of 24,52 years old. Only $16.66 \%$ of the participants 
reported that they had an experience on infant-toddler education and $41,66 \%$ of the participants mentioned that they had a specific course related to infant-toddler education. However, when the content of the courses identified by participants (exmp: Early Childhood Development I \& II, Maternal and Child Nutrition), it was seen that these courses are the main courses of the ECTE programs which are not specific to infanttoddler education. Similarly, the participants who were mentioned they had an experience with infantstoddlers mentioned the age of three not the younger children.

\section{Results}

In summary, results of the study indicated that all of the participants $(100 \%)$ think infancy-toddlerhood period is very important and has a crucial role for child's later development. While explaining the importance of this period almost all of the participants evaluated the period through a developmental perspective. That is, they stated that, infancy and toddlerhood is important since $80 \%$ of brain development occurs within this period, it is a period that fundamental milestones in the language, motor and social-emotional development occur at this stage. The majority of the participants $(67,5 \%)$ reported that center-based early childhood education is not appropriate for the children between 0-36 months of age. Similarly, majority of the participants $(59,1 \%)$ reported that they would not prefer to work with infants and toddlers. $55 \%$ of the participants thought that they are not qualified to work with infants and toddlers during their undergraduate education, while $19 \%$ of the participants reported that they are theoretically but not practically qualified to work with infants and toddlers. Among all, only 10\% of the participants reported that working with infant and toodlers is advantageous when compared with working with older children. Lastly, data revealed that there is not worthy difference among the opinions of pre-service early childhood educators who participated to the study in 2008, 2010, 2012, 2014 and 2015.

\section{Conclusion and Discussion}

According to the Howes, Phillips and Whitebook (1992), teacher education is one of the best predictor that determine the quality of infant-toddler education. For a qualitative infant toddler education, we need highly educated teachers in the field. However, in this study it was seen that fourth grade pre-service early childhood educators are not willing to work with infant and toddlers. This is a worrisome finding for the quality of center-based care and education provided by children under the age of three. Therefore, it can be claimed that in Turkey, early childhood teacher education programs are not fulfill their responsibility and they cannot successfully prepare preservice early childhood educators to work with children under the three. .One of the main arguments used by pre-service early childhood educators who does not want to work with infants and toddlers is the domination of care instead of education during infancy and toddlerhood period. According toGreenman and Stonehouse (1996), child care is the main opportunity for education during infancy and toddlerhood. By depending on Greenman and Stonehose's argument, it can be claimed that early childhood teacher education programs are not able to imbue its students with the idea that child care by itself is one of the best opportunity for education. In the study of Brownlee, Berthelsen and Segaran (2007), it has been found that both administrators and the educators think that having practice with children 
under the age of three is one of the main issue which resulted in quality infant-toddler care and education. In parallel with this results, in the current study it has been found that, lack of practice is one of the main reasons why pre-service early childhood educators feel themselves unqualified to work with infants and toddlers. In conclusion, this study revealed that pre-service early childhood educators do not prefer to work with infant and toddlers although they think that this period is so important for the development mainly because of feeling unqualified and unexperienced. 


\section{GİRİŞ}

Yaşamın ilk üç yılı, anne karnında gerçekleșen ve muazzam bir hıza sahip olan gelişim sürecinin benzer bir hızla devam ettiği, ileriki gelişim süreçlerinin sağlıkla tamamlanması için gerekli temellerin atıldığı oldukça önemli ve değerli bir dönemdir. Birçok gelişim alanı için kritik dönemleri içeren bu süreç boyunca bireyin dil becerileri, motor becerileri ve benlik algısı gibi temel yapıtaşları gelişmekte (Calkins, 2007) ve birey yürümek, iletişim kurmak, akıl yürütmek ve sorun çözmek gibi birçok temel beceriyi edinmektedir (MEB,2013). Alan yazında var olan tüm çalışmaların buluştuğu ortak payda, bu kritik süreçte çocuğun gelişimini etkileyen en temel faktörün gerek kurumlarda gerekse evde, bebekle kurulan duyarlı ve uyarıcı bir ilişki olduğudur (Clarke-Stewart, Vandell, Burchinal, Brien, ve McCartney, 2002; Phillips, Mekos, Scarr, McCartney, ve Abbott-Shim, 2000). $\mathrm{Bu}$ nedenle, bebeklerin bu süreçte kimlerle olduğu ve onlara bakım ve eğitim sunan yetişkinlerin yeterlilikleri oldukça önemlidir.

Ülkemizde çalışan anne ve babaların, 0-5 yaş aralığındaki çocuklanı çoğunlukla kurum dışı ortamlarda bakım görmektedir. TUIK (2016) tarafından hazırlanan Türkiye Aile Yapısı Raporuna göre anne ve babası çalışan 0-5 yaş aralığındaki çocukların sadece \%20'si kurum temelli eğitim ve bakım almaktadır (Dünya, 2017). Bu durum, 0-2 yaş aralığında \%1'in altındadır (ERG ve AÇEV,2017). Geri kalan bebeklerin ise, çoğunlukla büyükanneler, akrabalar veya bakıcılar tarafından bakıldığı bilinmektedir. Bu durumun sonucu olarak çocuklar formal eğitime hatta formal eğitimden önce okul öncesi eğitime birbirinden çok farklı altyapılarla başlamaktadırlar. $\mathrm{Bu}$ farklılığın önüne geçebilmek ve çocuklar arasında firsat eşitliğini yaratabilmek için, 0-3 yaş aralığında eğitim veren kaliteli kurum sayısının artması günümüz koşullarında bir zorunluluk haline dönüşmektedir.

Aile ve Sosyal Politikalar Bakanlı̆̆ı, ilgili yönetmeliklerinde bu eğitim kurumlarında görev alacak eğitimciler için "grup sorumlusu” tabirini kullanmaktadır ve bu kişilerin seçiminde bir kriter olarak “Kreş ve gündüz bakımevlerinde görevlendirileceklerin yükseköğretim kurumlarının çocuk gelişimi ve eğitimi öğretmenliği, okul öncesi eğitimi öğretmenliği, anaokulu öğretmenliği, çocuk gelişimi ve eğitimi bölümü, çocuk gelişimi bölümü lisans veya ön lisans mezunları öncelikli olmak üzere kız meslek liselerinin çocuk gelişimi ve eğitimi bölümü mezunu olmaları” gerektiğini belirtmektedir. Ancak, ülkemizde genelde bebeklik döneminde eğitime (Aksoy ve Koran, 2016) özelde ise bu kurumlarda çalışması ön görülen okul öncesi öğretmen adaylarının 0-36 aylık çocuklarla çalışmaya yönelik ne düşündüklerine ya da nasıl hazırlandıklarına dair neredeyse hiçbir çalışma bulunmamaktadır. Bu nedenle, bu araştırmanın amacı okul öncesi öğretmen adaylarının bebeklik döneminin önemine ve bebeklik dönemi eğitimine yönelik görüşlerini ortaya koymak ve bu 
görüşlerin bebeklik döneminde eğitime ilişkin farkındalığ1 etkileyecek birçok gelişmenin yalandığ1 2008-2015 yılları arasında son sınıf öğrencisi olan öğretmen adayları arasında değişip değişmediğini incelemektir. Bu hedef doğrultusunda aşağıdaki araştırma sorularına yanıt aranmıştır;

I. Okul öncesi öğretmen adaylarının bebeklik döneminde kurum temelli eğitime ilişkin görüşleri nelerdir?

a. Okul öncesi öğretmen adaylarının bebeklik döneminin önemine ilişkin görüşleri nelerdir?

b. Okul öncesi öğretmen adayları bebeklik döneminde çocukların kurum temelli eğitim almasına yönelik görüşleri nelerdir?

c. Okul öncesi öğretmen adayları bebeklik dönemindeki çocuklarla çalışmaya ilişkin görüşleri nelerdir?

II. Farklı yıllarda çalışmaya katılan okul öncesi öğretmen adaylarının bebeklik döneminde eğitime yönelik görüşleri farklılaşmakta mıdır?

Aksoy ve Koran (2016) tarafindan da önerildiği üzere, bebeklik döneminde eğitime yönelik yapılacak araştırmalar bu dönemde verilecek eğitime ve bu eğitimin önemine ilişkin algılları da ortaya çıkaracak ve daha da önemlisi giderek şekillendirecektir. Bu bağlamda bu araştırma ilgili alan yazında var olan önemli bir bilgi eksikliğini giderecektir. Geleceğin okul öncesi öğretmenlerinin, bebeklik döneminde eğitime ilişkin görüşlerinin ortaya konması var olan durumdaki eksiklikleri de ortaya çıkaracak ve okul öncesi öğretmen yetiştirme programları ve eğitim politikalarına ilişkin yeni ve önemli bir tartışmanın ilk adımını oluşturacaktır. Bu durum, bebeklik döneminde yapılacak yeni araştırmaların da önünü açarak bebeklik döneminde eğitime ilişkin yeni bir alan yazının oluşmasına katk1da bulunabilir.

\section{Bebeklik dönemi ve önemi}

Doğum öncesi dönemde başlayan ve hayatın ilk üç yllında devam eden süreç, bir bireyin gelecek yaşantısında uzun solukluk bir etkiye sahiptir (Woody, 2007, s. 100). Oturmak, emeklemek, ayakta durabilmek ve yürümek gibi en temel motor beceriler bebeklik döneminin ilk bir yllinda edinilmektedir (MEB, 2013). Benzer bir şekilde, bilişsel gelişimin desteklenmesi için de bebeklik dönemi sürecindeki deneyimler kritik bir öneme sahiptir. Zigler, Finn-Stevenson, ve Hall (2002) nöronların oluşumu ve birbiri ile iletişiminin güçlendiği bir dönem olan bebeklik döneminin beyin gelişimi için kritik bir dönem olduğuna vurgu yapmıştır. Shonkoff ve Phillips (2000) ise sağlıklı bir beyin gelişimini beslemek ve desteklemenin ancak bebeklik dönemi süresince bireyin fiziksel ve psikolojik ihtiyaçlarının pozitif bir şekilde karşılanması durumunda gerçekleşeceğini belirtmiştir. 
Sağlıklı bir beyin gelişimi bilgiyi işleme, saklama ve problem çözme gibi becerilerin, yani bilişsel gelişimin temelini oluşturmaktadır (Woody,2007). Bu bağlamda, bebeklik dönemi süreci bilişsel gelişim sürecinde, nesne devamlılı̆̆1, sembolik düşünme gibi önemli bilişsel becerilerin edinildiği bir süreçtir (Piaget, 1952). Dil gelişimi bilişsel becerilerle paraleldir ve doğumda ağlamak dışında hiçbir iletişim becerisini kullanamayan bir bebek, ilk üç yllın sonunda neredeyse bir yetişkinin dil becerilerine benzeyen bir gelişim göstermektedir. Bu nedenle, bebeklik döneminde yetişkinlerle ve diğer çocuklarla gerçekleşecek olan etkileşimler bireyin dil gelişimini olumlu yönde etkileyecektir. Bebeklik döneminde temelleri atılan bir diğer gelişim alanı ise sosyal duygusal gelişimdir. Erikson (1950) insanın yaşamının sekiz farklı çağdan oluştuğunu iddia etmiş ve hayatın ilk üç yllının bireyin kendisine, çevresindekilere ve dünyaya güven duyma ve özerklik kazanmada oldukça kritik dönemler olduğunu vurgulamıştır. Benzer bir şekilde, bağlanma kuramını ortaya atan Bolbwby (1982; akt. Metin Orta ve Sümer, 2016) ve ardından kuramı genişleten Ainsworth ve arkadaşları (1978), hayatın ilk yılında bireyin öncelikle annesi ve sonrasında çevresinde bulunan ve bakımında etkin rol oynayan diğer kişilerle kurduğu bağın gelecekte kuracağı tüm sosyal ilişkilerin temelini oluşturduğunu iddia etmişlerdir. Tüm bu önemli dönemlerde bireyin güvenebileceği, ihtiyaçlarını doğru ve uygun şekilde karşılayan ve çocuğun gelişimini desteklemek noktasında yetkin yetişkinlerle olması, bireyin gelecek yaşantısı için oldukça önemli bir noktadır. Günümüz yaşam koşullarında özellikle çalışan annelerin doğum sonrasında çalısma hayatına geri dönebilmesi için bebeklik döneminde kurum temelli eğitim ihtiyaç duyulan bir seçenek haline dönüşmektedir.

\section{Bebeklik döneminde kurum temelli eğitim}

Ülkemizde, bebek bakımı ve eğitimine yönelik yaygın kabul gören düşünce, bebeklerin en az 3 yaşına kadar anneleri tarafindan bakılmaları yönündedir (ERG ve AÇEV,2017). Ancak, günümüzde bir ailenin geçimini sağlayabilmesi için her iki ebeveynin de çalışması neredeyse zorunlu hale gelmiştir. Bu nedenle günümüzde, bebeklik döneminde eğitime ilişkin ebeveynler ve toplum tarafından genel kabul gören görüş, bebeklik döneminde çocuğun fiziksel ve duygusal ihtiyaçlarının doğru bir şekilde karşılanırken, ebeveynlerin de bu süreçte iş hayatına aktif katılımının desteklenebilmesidir (Brownlee ve diğerleri, 2007).

0-36 aylık dönem, çocuğun tüm yaşamını etkileyebilecek güce sahiptir ve bu dönemde edinilen deneyimler ileride gelişimi olumlu yönde destekleyecektir. Diğer yandan yaşamın ilk üç yıllında yetersiz ve kalitesiz bir ortama maruz kalan çocukların hayatlarında oluşacak açı̆̆ı kapatma şanslarının düşük olduğu belirtilmektedir (Bayhan ve Artan, 2004; Damast, Tamis-LeMonda, ve Bornstein, 1996). Bu nedenle, çocuğun fiziksel ve duygusal ihtiyaçlarını doğru bir şekilde karşılarken, entelektüel gelişim de dahil olmak üzere bebeğin tüm gelişim alanlarını dengeli bir 
şekilde ve bütüncül bir bakış açısıyla destekleyecek kaliteli bir bebeklik dönemi eğitimi verilmesi önemlidir (Edwards ve Reikes, 2012; Greenman ve Stonehouse, 1996).

Kurum temelli bebeklik dönemi eğitimine dair en yaygın görüşün bebeğin bağlanma sürecinin kurum temelli bir eğitim deneyiminden olumsuz etkileneceği yönündedir. Alan yazında bu argümanı destekleyen çalışmalar olsa da (Belsky, 1987; Belsky ve Braungart, 1991), kurum temelli eğitimin bebeklik ve erken çocukluk dönemi bağlanması üzerinde negatif bir etkisinin olmadığını (Griffith, 1996; Shonkoff ve Phillips, 2000), hatta kurum temelli eğitimin güvensiz anne çocuk bağlanmasının olumsuz sonuçlarını hafiflettiğini gösteren çalışmalar da bulunmaktadır (Spieker,Nelson, ve Petras, 2003). Clarke-Stewart ve diğerlerinin (2002) yaptığı bir çalışmanın sonuçlarına da, kanunlarla düzenlenen kurum temelli bebeklik dönemi eğitimi ve bakımının, bebeklerin gelişimini diğer tüm bakım ortamlarından çok daha olumlu etkilediğini göstermiştir. Ancak tüm bu olumlu sonuçlar, bebeklik döneminde eğitim veren kurumların ve kurumlarda çalışan eğitimcilerin kaliteli olmasıyla yakından ilişkilidir. Eğitimciler, erken çocukluk eğitiminin her basamağında bir kurumun kalitesini etkileyen en önemli unsurlardan biridir; ancak yaşça büyük çocuklarla karşılaştırıldığında bebeklik dönemindeki çocuklar bakım ve eğitim ortamındaki yetişkinlere çok daha fazla ihtiyaç duymaktadırlar (Bieth, Penny, Bulman ve Robinson, 2005; Brownlee ve diğerleri, 2007). Bu nedenle, daha küçük yaşlardaki bu çocuklar kalitesiz bir eğitim ortamından ve iyi yetişmemiş eğitimcilerden çok daha olumsuz etkilenirler (Karp, 2006; Whitebook, 2003). Bu durum, bu dönemde çocuklarla çalışacak kişilerin kaliteli öğretmenler olmasını zorunlu hale getirmektedir. Öğretmenin kalitesini belirleyen en önemli unsur ise aldığ1 eğitim ve sahip olduğu deneyimdir. Kaliteli bir bebeklik dönemi eğitimi, alanında uzman, kaliteli öğretmen yetiştirme programlarından mezun olmuş, öğretmen kimliğ̣i kuvvetli öğretmenler tarafindan verilebilir.

\section{Bebeklik döneminde eğitim programı}

Türkiye'de bebeklik döneminde eğitime ilişkin ilk program 1994 yllında yayımlanmıştır. 0-3 Yaş Kreş Programı olarak isimlendirilen bu program, 2012 yılına kadar kullanılmıştır. Bu süreçte Okul Öncesi Eğitim Programı 2002 ve 2006 yıllarında güncellenmiş ancak Kreş Programı kullanılmaya devam etmiştir. Akman (2013) 1994 yllında hazırlanmış olan Kreş Programının yeterince yaygınlaştırılamadığını, bu nedenle bebeklik dönemindeki çocuklara eğitim veren kurumların kendi programlarını hazırladıklarını belirtmiştir. Mart 2010 yılında başlayan Okul Öncesi Eğitimi Güçlendirme Projesi kapsamında yeniden ele alınan Kreş Programı, 2012 yılında revize edilerek ve “0-36 Aylık Çocuklar için Eğitim Programı”’na dönüştürülmüştür. 
2006 yllında gerçekleştirilen okul öncesi eğitim programı revizyonunun ardından günümüze kadarki süreçte, okul öncesi eğitimle ilgili birçok politika uygulanmıştır. Örneğin, 2008-2009 eğitim öğretim yılında 32 ilde 60-72 aylık çocuklar için zorunlu okul öncesi eğitim uygulaması başlatılmışır (AÇEV ve ERG, 2016). Bu uygulama 2010-2011 eğitim öğretim yllında 57 ve 2011-2012 eğitim öğretim yılında ise 71'e çıkarıldı (AÇEV ve ERG, 2016). Okul öncesi eğitimde 60-72 aylık çocukların zorunlu okul öncesi eğitime dahil olması, çocukların daha küçük yaşlarda okul öncesi eğitim kurumlarına dahil olmasını sağlayabilecek bir uygulama idi. Bunun yanı sıra, 2010 yılında Avrupa Birliği'nin mali ve UNICEF'in teknik desteğiyle Okul Öncesi Eğitimin Güçlendirilmesi Projesi de 10 pilot ilde başlatıldı. Projenin amacı, "kamu kurumları, belediyeler ve STK'ların kapasitesi ile toplum temelli modeller ve ortaklıkların geliştirilmesi yoluyla dezavantajlı çocuklar ve aileleri için kaliteli gündüz çocuk bakım ve okul öncesi eğitim hizmetlerinin geliştirilmesi ve oluşturulması" şeklinde tanımlanmıştır (AÇEV ve ERG, 2016, p. 14). Görüldüğü üzere, gündüz çocuk bakımı Okul Öncesi Eğitimi Güçlendirme Projesi kapsamında özellikle ele alınmış, bunun yanı sıra proje kapsamında 0-36 aylık çocukların eğitim sürecine odaklanılmış, var olan kreş programının etkililiğinin araştırılmıss ve program revize edilmiştir. Tüm bu durumlar da bebeklik döneminde eğitimin canlanmasını sağlayabilecek önemli girişimlerdendir. Ne yazık ki, hem bu girişimlerin 0-36 aylık çocukların okullaşma oranını nasıl etkilediğine hem de " 0 -36 aylık çocuklara yönelik geliştirilen eğitim programının Aile ve Sosyal Politikalar Bakanlığı (ASPB)'ye bağlı kurumlarda uygulamaya girmiş olup olmadığına ve/veya ne kadar etkili bir şekilde uygulandığına" dair herhangi bir veri bulunmamaktadır (AÇEVve ERG, 2016, p.28). Yine de alanda atılan bu önemli adımlara, öğretmen yetiştirme programlarında yer verilmesi durumunda, bu süreçlerin öğretmen adaylarının bebeklik döneminde eğitime ilişkin görüşlerini etkileyerek öğretmenlik kimliklerine etki etmiş olabileceği düşünülmektedir.

\section{Bebeklik dönemine yönelik öğretmen eğitimi}

Öğretmen kimliği, bir öğretmenin öğretmen olarak kim olduğuna dair inançlarını ifade etmektedir. Diğer bir deyişle, bir okul öncesi öğretmeninin, mesleğine atfettiği tüm özellikler onun öğretmen kimliğini etkileyecek inançlarıdır. Bu kimliğin oluşumunda önemli olan iki faktör; bireyin sahip olduğu değerler, inanışlar ve deneyimler ile öğretmen olma yolunda ilerlerken aldığı eğitim sürecinde edindiği bilgi ve deneyimlerdir (Chang-Kredl ve Kingsley, 2014; Egan, 2007; Gibson, 2013; Pearce ve Morrison, 2011). Bir okul öncesi öğretmeninin profesyonel kimliği, hem kendi değerlerinin, deneyim ve inançlarının hem de öğretmen yetiştirme programında edindiği bilgi, beceri ve deneyimlerin harmanlanması ile ortaya ç1kar (Chang-Kredl ve Kingsley, 2014; Pearce ve Morrison, 2011; Thomas, 2012). Benzer bir şekilde Chalke (2013) öğretmen yetiştirme 
programlarının, bir öğretmenin sadece bilgi ve beceri düzeyini değil aynı zamanda onun değerlerini de şekillendirdiğini vurgulamıştır. Bu noktada, bir okul öncesi öğretmeninin bebeklik dönemindeki çocuklarla çalışmaya yönelik ilgi ve isteği hem bireyin bu döneme ilişkin sahip olduğu bilgi ve bu döneme atfettiği değerden hem de eğitimi sürecinde bu döneme ilişkin almış olduğu bilgilerden, edindiği deneyim ve tecrübelerden etkilenecektir. Araştırmalar, bebeklerin kurum temelli eğitimden sağladığı faydanın, öğretmenlerinin bebeklik dönemine ilişkin bilgileri daha fazla olması ve bu bilgileri uygulamaya yansıtmakta yetkin olması durumunda arttığını göstermiştir (Angus ve CarrollLind, 2011; Dalli ve diğerleri., 2011). Benzer şekilde, yüksek eğitim düzeyine sahip olmanın ve bebeklik dönemine ilişkin özel bir eğitim almış olmanın, bebeklik döneminde eğitim programlarının kalitesini belirleyen önemli değişkenler olduğu bulunmuştur (Burchinal, Roberts, Riggins, Zeisel, Neebe, ve Bryant, 2000; Kreader, Ferguson, ve Lawrence, 2005b). Howes, Phillips and Whitebook (1992) bir öğretmenin sahip olduğu formal eğitim düzeyinin, o öğretmenin duyarlılı̆̆ını ve genel uygulamalarını yordayan en güçlü değişken olduğunu vurgulamıştır. Söz konusu bebekler olduğunda ise, erken çocukluk eğitimi alanında uzmanlaşmış kişilerin çok daha yüksek kalitede eğitim ve bakım hizmeti sunduğu ortaya konmuştur (Howes, Phillipsve Whitebook, 1992).

Türkiye'de 0-36 aylık çocuklar için eğitim hizmeti sunan okul öncesi eğitim kurumları, Aile ve Sosyal Politikalar Bakanlığı’na bağlıdır ve 0-35 aylık çocuklara kamu hizmeti götürülmesini öngören yasal bir düzenleme bulunmamaktadır (Dünya Bankası, 2015). 0-36 aylık çocuklara hizmet sunacak olan özel kurumlar için ise kalite standartları, Aile ve Sosyal Politikalar Bakanlığı'nın 30 Nisan 2015’te yayınladığ1 Özel Kreş ve Gündüz Bakım Evleri ile Özel Çocuk Kulüplerinin Kuruluş ve İşleyişs Esasları Hakkında Yönetmeliği ile belirlenmektedir. Bu yönetmelik daha çok kurumların açılması ve işletilmesine ilişkin bürokratik süreçlere, fiziksel ortamın düzenlenmesine ve kurumların yasal sorumluluklarına odaklanmaktadır. Yönetmelik, kurum temelli eğitimde kaliteyi belirleyen en önemli faktörlerden biri olan eğitimcilerin eğitim düzeyine ilişkin çok esnek kurallara sahiptir. Buna göre kreş ve gündüz bakımevlerinde görevlendirilecek kişilerin ““‘çocuk gelişimi ve eğitimi öğretmenliği, okul öncesi eğitimi öğretmenliği, anaokulu öğretmenliği, çocuk gelişimi ve eğitimi bölümü, çocuk gelişimi bölümü lisans veya önlisans mezunları öncelikli olmak üzere kız meslek liselerinin çocuk gelişimi ve eğitimi bölümü mezunu olmaları” gerektiği belirtilmektedir.

Tüm bu bilgiler, çocuklarla çalışacak olan öğretmenlerin bu alana nasıl hazırlandığına dair bilgi sahibi olmamız gerektiğine vurgu yapmaktadır (Karp, 2006). Aksoy ve Koran (2016), ülkemizde gerçekleştirilmiş bebeklik dönemine ilişkin araştırmaları incelemişlerdir. Araştırmanın sonuçları bebeklik dönemine ilişkin ülkemizde gerçekleştirilen ve ulusal dergilerde yayınlanan araştırmaların sadece \%5'inin, yurt dışında yayınlananların ise sadece \%7,5'inin eğitim alanındaki akademik 
dergilerde yayımlandığını göstermiştir. Diğer bir deyişle, yurt dışı dergilerinde yayımlanan toplam 20 araştırmanın 3'ü, ülkemizde yayımlanan toplam 20 araştırmanın ise sadece 2'si eğitimle ilişkili dergilerde yayımlanmıştır (Aksoy ve Koran, 2016, s. 369). Benzer bir şekilde, Metin, Akbaş, Yıldız ve Özaydın (2017) yaptıkları araştırmada, 1994 ve 2016 yılları arasında Türkiye'de gerçekleştirilmiş ve 0-36 aylık çocuklarla ilgili olan tezleri incelemiş ve çocukların eğitimine odaklanan bir tanesi normal gelişim gösteren çocukların eğitimiyle ilgili olmak üzere toplamda beş tez adet olduğunu ortaya koymuştur.

Sonuç olarak, ülkemizde bebeklik döneminde eğitim verecek öğretmenlerle ilgili olarak yapılan araştırmaların çok az sayıda olduğu ve bu alanda özellikle bebeklik dönemi eğitiminde görev alması beklenen okul öncesi öğretmenleri ve öğretmen adaylarıyla yapılan hiçbir çalışmanın olmadığ1 görülmektedir. Bu alandaki araştırmaların yetersizliği okul öncesi öğretmen ve öğretmen adaylarının eğitimine de yansımakta ve mezuniyet sonrası okul öncesi öğretmenliği bölümü mezunları bebeklik döneminde eğitim veren kurumlarda çalışmaktan ve bebeklerle çalışmaktan kaçınmaktadırlar. $\mathrm{Bu}$ nedenle, mevcut araştırma okul öncesi öğretmen adaylarının bebeklik dönemine ilişkin görüşlerini ortaya çıkararak bu alanda yapılacak gelecek çalışmalar için önemli bir ilk adım olacaktır.

\section{YÖNTEM}

Bu çalışma, betimleyici nitel araştırmadır (Sandelowski, 2000). Doğal araştırma modeline dayanan, betimleyici nitel araştırmaların temelinde katılımcılardan elde edilen verilerin araştırmacının yorumuna uğratılmaksızın betimlenmesi yatmaktadır (Sandelowski, 2000). Diğer bir deyişle, Sandelowski'ye göre betimleyici nitel araştırma deseninde araştırmacı ilgili olguya yönelik katılımcıların söylemlerini yeniden yorumlama ya da olgunun özüne ulaşmaya çalışmak yerine katılımcıların olguya yönelik kullandıkları söylemlerdeki gerçekliği ortaya koymayı hedefler. Mevcut çalışmanın da temel amacı, okul öncesi öğretmen adaylarının bebeklik döneminde kurum temelli eğitime yönelik görüşlerini betimlemek ve ortaya çıkan görüşlerin bebeklik döneminde eğitime vurgu yapan birçok gelişmenin yaşandığı 2008-2015 yılları içerisinde değişime uğrayıp uğramadığını ortaya koymaktır.

\section{Katılımcilar}

Amaçlı örnekleme nitel araştırmalarda olguya ilişkin en zengin datayı sunabilecek kişilerle çalışmayı sağlamak amacıyla yaygın olarak kullanılan bir örnekleme yöntemidir (Patton, 2002; Palinkas ve diğerleri., 2015). Çalışmada amaçlı örneklem yöntemlerden tipik durum örneklemesi kullanılmıştır. Tipik durum çalışılan olguya ilişkin ortalama özelliklere sahip kişilerin çalışmaya dahil edilmesini 
hedeflemektedir (Miles ve Huberman, 1994, s.28). Çalışmanın amacı lisans eğitiminin sonuna gelmiş olan öğretmen adaylarının bebeklik döneminde eğitime ilişkin görüşlerini betimlemek olduğundan çalışmanın verileri 2008, 2010, 2012, 2014 ve 2015 yıllarında dördüncü sınıf öğrencisi olan toplamda 120 okul öncesi öğretmen adayından toplanmıştır. Aynı üniversitede öğrenim gören 2008 yılında 20 öğretmen adayı, 2010 yılında 25 öğretmen adayı, 2012 yılında 35 öğretmen aday1, 2014 yılında 25 öğretmen adayı ve son olarak 2015 yılında 15 öğretmen adayı çalışmaya katılmıştır. Çalışmaya katılan öğretmen adaylarının demografik özelliklerine ilişkin elde edilen bulgular Tablo 1'de özetlenmiştir.

Tablo 1. Kat1lımciların Demografik Özellikleri

\begin{tabular}{|c|c|c|}
\hline Katılımcıların yaşı & $\begin{array}{l}\text { Min: } 21 \\
\text { Max:35 }\end{array}$ & Ort: 24,52 \\
\hline Katılımcıların cinsiyeti & $\begin{array}{l}\text { K: } 110 \\
\mathrm{E}: 10\end{array}$ & \\
\hline $\begin{array}{l}\text { Daha önce } 0-3 \text { yaş dönemindeki çocuklarla } \\
\text { uygulama deneyimi olan katılımcı sayısı }\end{array}$ & $\% 16,66$ & $\begin{array}{l}\text { Bu soruya olumlu yanıt veren } 20 \\
\text { katılımcı, sadece } 3 \text { yaş grubu ile } \\
\text { uygulama yaptıklarını beyan } \\
\text { etmişlerdir. }\end{array}$ \\
\hline $\begin{array}{l}\text { Daha önce } 0-3 \text { yaş dönemindeki çocukların } \\
\text { eğitimine yönelik ders alan katılımcı sayısı }\end{array}$ & $\% 41,66$ & $\begin{array}{l}\text { Bu soruya olumlu yanıt veren } \\
\text { katıllımcıların belirttiği dersler, } \\
\text { Erken Çocukluk Döneminde } \\
\text { Gelişim I ve II, Okul Öncesi } \\
\text { Eğitime Giriş, Anne-Çocuk Ruh } \\
\text { Sağlığı gibi programda yer alan 0-6 } \\
\text { yaş grubunu kapsayan derslerdir. }\end{array}$ \\
\hline
\end{tabular}

Tablo 1'de görüldüğü üzere, katılımcıların ortalama yaşı 24,52 ve büyük çoğunluğu kadındır. Sadece 20 katılımcı, bebeklik dönemindeki 0-36 aylık çocuklarla deneyimi olduğunu beyan etmiştir. Ancak, bu katılımcıların hepsi sadece 3 yaş grubu çocuklarla uygulama yaptıklarını belirtmiştir. Katılımcıların \%41,66’sı eğitimleri süresince, bebeklik dönemine ilişkin ders aldıklarını beyan etmiştir. Öğretmen adaylarından bebeklik döneminde eğitime ilişkin aldıkları derslerin isimleri istendiğinde verilen cevaplar Erken Çocukluk Döneminde Gelişim I ve II, Okul Öncesi Eğitime Giriş, Anne-Çocuk Beslenmesi, Çocuk Ruh Sağlığı gibi temelde 0-6 yaş dönemini kapsayan, dersin bir kısmında bebeklik dönemine dair bilgi sunulan ve özelde bebeklik döneminde eğitime ilişkin olmayan dersleri kapsamaktadır.

\section{Veri toplama süreci:}

Veriler, araştırmacının hazırladığı beş açık uçlu sorudan oluşan yazılı görüşme formu aracılı̆ğ ile elde edilmiştir. Çalışma da kullanılan bu yazılı görüşme formunun geçerliliğini arttırmak amacıyla Şimşek ve Yıldırım (2005) tarafindan önerilerin formu uzman görüşüne sunma yöntemi 
kullanılmıştır. Hazırlanan yazılı görüşme formu, okul öncesi öğretmenliği ABD 'da görev yapan iki farklı öğretim elemanı tarafından değerlendirilmiş ve önerilen değissiklikler yapılmıştır. Yazılı görüşme formları, gerçek uygulamalardan önce üç son sınıf öğrencisine uygulanmış ve anlaşılmayan noktalar düzenlenmiştir. Tüm anketler uygulandıklar1 yıllarda dördüncü sinıfta okuyan öğretmen adaylarına, sınıf ortamında, araştırmacının kendisi tarafindan uygulanmıştır. Nitel araştırmalarda katılımcıların çalışmaya gönüllü katılımı, çalışmanın geçerliliğini arttıran önemli bir unsurdur (Yıldırım ve Şimşek, 2005). Bu nedenle, her veri toplama sürecinin başında öğretmen adaylarına soruları cevaplamak zorunda olmadıkları, yazılı formlara isimlerini ya da kimliklerini belirten bir ifade eklemelerine gerek olmadığı, elde edilen verilerin araştırma amaçlı kullanılacağı ve gerekli sürenin bitiminden sonra verilerin imha edileceği, istedikleri anda soruları cevaplamaktan vazgeçebilecekleri bilgisi verilmiştir. Bu yolla gönüllü katılımcıların çalışmaya devam etmesi ve verdiklerin cevapların gerçeği daha fazla yansıtması amaçlanmıştır. Yıldırım ve Şimşek (2005) tarafından önerilen ve geçerliliği arttıran bir diğer yöntem ise katılımcı teyididir. Bu çalışmada veriler yazılı olarak alındığı için her katılımcıdan kendi cevapları üzerine bir teyit almak mümkün olmamıştır. Ancak verilerin toplanmasının ardından araştırmacı tüm yanıtları okumuş ve bir sonraki derste katılımcıların cevapları üzerine sınıfta bir tartışma ortamı yaratmıştır. Bu süreçte verilerin bir özeti ve araştırmacının yorumları katılımcılara sunulmuş ve yorumların doğruluğu üzerine konuşulmuştur. Bu konuşma esnasında araştırmacı gerekli notları tutarak bu notları da verilerin yorumlanmasında kullanmıstır. Verilerin toplanma süreci ortalama olarak 22,63 dakika sürmüştür.

\section{Verilerin analizi:}

Sandelowski (2000) betimleyici nitel araştırma deseninde kullanılan en temel veri analiz yönteminin nitel içerik analizi olduğuna vurgu yapmaktadır. İçerik analizi yöntemlerinden, Hsieh ve Shannon (2005) tarafindan geleneksel içerik analizi olarak adlandırılan, kodların ve kategorilerin verinin kendisinden çıkarıldığ1 yöntem kullanılmıştır. Bu amaçla, içerik analizi verilerin tümünün açık kodlama yöntemi ile kodlanmasıyla gerçekleştirilmiştir. İlk kodlamalar yapılırken yıllara göre bir karşılaştırma yapılmamış genel kodlar ve kategoriler belirlenmiştir. Genel kodlamanın bitmesinin ardından, yıllara göre bu kodların yüzdeleri hesaplanmıştır.

Araştırmanın geçerliliğini artıımak amacıyla, Yıldırım ve Şimşek (2005) tarafından önerilen araştırmacı çeşitliliği yöntemi kullanılmış ve verilerin \%25’i araştırmacı haricinde, okul öncesi öğretmenliği ABD'de doktora eğitimine devam eden ve nitel araştırma tecrübesi olan bir araştırmacı tarafından da kodlanmıştır. Her iki araştırmacı tarafından yapılan kodlamalar arasında \%80’lik bir uyum olduğu gözlemlenmiştir. Uyumsuzluklar tartışma yoluyla giderilmiştir. 


\section{BULGULAR}

Mevcut çalışma, iki temel amaç doğrultusunda gerçekleştirilmiştir; (1) okul öncesi öğretmen adaylarının bebeklik döneminde kurum temelli eğitime ilişkin görüşlerini betimlemek, (2) farklı yıllarda son sınıf öğrencisi olan okul öncesi öğretmen adaylarının bebeklik döneminde kurum temelli eğitime ilişkin görüşlerinde bir farklılık olup olmadığını ortaya koymak. Bu bağlamda, çalışmanın bulguları iki farklı bölümde sunulacaktır. İlk bölümde yıllar arasında bir karşılaştırma yapılmayacak, 120 katılımcıdan elde edilen verilerden ortaya çıkan kodlar ve kategoriler sunulacaktır. İkinci bölümde ise, ortaya çıkan kategoriler yıllara göre karşılaştırılacaktır.

\section{Bölüm I}

Bu bölümde, öğretmen adaylarının yazılı görüşme formunda yer alan beş açık uçlu soruya verdikleri yanıtlardan ortaya çıkan kodlar ve kategoriler sunulacaktır. Yazılı görüşme formundaki ilk soru, " 0 36 aylık dönemin önemli olduğunu düşünüyor musunuz? Neden?” sorusudur. Bu soruya araştırmaya katılan tüm öğretmen adayları, olumlu yanıt vermiştir. Öğretmen adaylarının, bebeklik döneminin öneminden bahsederken "gelişim" temelli bir yaklaşım içerisinde oldukları belirlenmiştir. Diğer bir deyişle, öğretmen adayları bu dönemi değerlendirirken, dönemin gelişimsel açıdan önemine odaklanmıştır. Bebeklik döneminin önemine ilişkin olumlu görüşler "Bu dönemde gelişim çok hızlıdır”, "Bu dönemde kişiliğin temeli atılır, gelecek yıllarda ise kişilik bu temel üzerinden şekillenir.”, “0-3 yaş dönemi kritik dönemleri kapsar” ve "çocuğun bilişsel gelişiminin \%80’i bu dönemde gerçekleşir” gibi argümanlarla açıklanmıştır.

Yazılı görüşme formunda ilk soruyu takip eden diğer üç soruya verilen cevaplara ilişkin genel bir özet Şekil 1'de verilmiş, her sorunun analizi ayrıntılı bir şekilde ilerleyen bölümlerde sunulmuştur. 


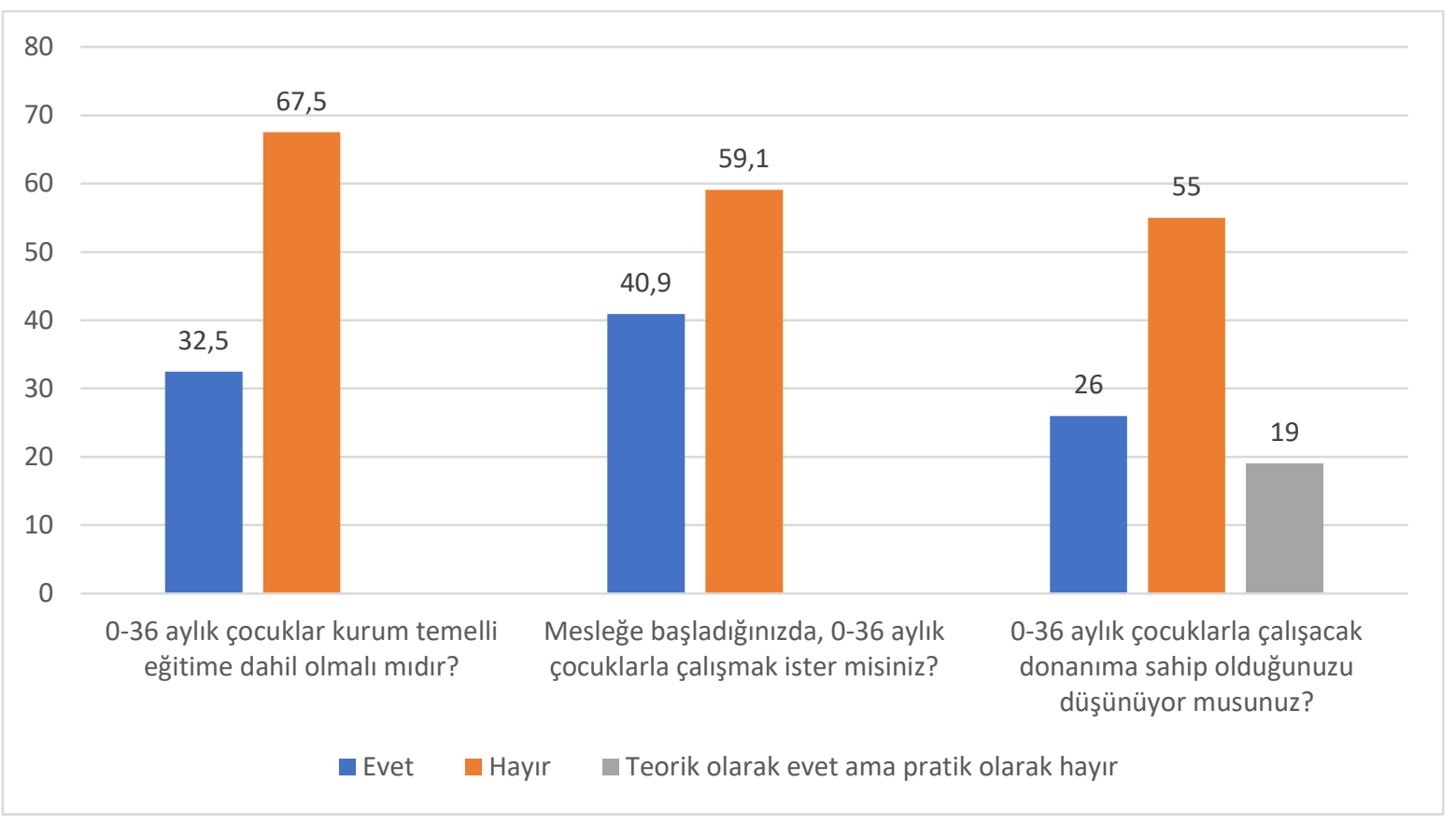

Şekil 1. Yazıll görüşme formu sorularına verilen görüşmelerin yüzdelikleri 
Görüşme formunda yer alan ikinci soru, "0-36 aylık dönemde bebekler okul öncesi eğitime dahil olmalı mıdır? Neden?" şeklindedir. Katılımcıların yaklaşık \%68’i bu soruya "bu dönemde çocuklar eğitime dahil olmamalıdır” yanıtını vermiştir. Katılımcıların sadece \%32,5’i 0-36 aylık çocukların erken çocukluk eğitim sürecine dahil olması gerektiğini düşündüklerini belirtmiştir. Bu soruya olumsuz yanıt veren grubun sunduğu nedenler ile soruya olumlu yanıt veren \%38'lik grubun sunduğu nedenler açık kodlama yöntemi ile analiz edilmiş ve Tablo 2'deki kategoriler ortaya çıkmıştır.

Tablo 2. 0-36 aylık çocukların kurum temelli eğitime katılma ya da katılmama gerekçelerine dair katılımcı görüşleri

\begin{tabular}{lll}
\hline & \multicolumn{2}{c}{ HAYIR } \\
\hline Kategori İsmi & Örnek Kod & Kategorinin tanımı \\
\hline Aileye duyulan & «Gitmemeli. Bu yaş grubunda çocuklar daha & Bu kategoride, eğitimci adayları 0-36 aylık \\
ihtiyaç & çok anne ilgisine ihtiyaç duyarlar. Anne ve & dönemde bebeğin daha çok anne bakımına \\
& baba ile daha çok vakit geçirmeli bu & ihtiyaç duyduğunu belirtmiştir. \\
& dönemde»
\end{tabular}

\begin{tabular}{ll}
\hline Kurumda ilgi & «...çocukların 3 yaşına kadar bire-bir ilgi ve \\
yetersizliği & sevgiye ihtiyaçları olduğunu düşünüyorum. \\
& Kreşlerde her çocukla her zaman teker teker \\
& ilgilenilmiyor...» \\
& «hiç bir okul öncesi öğretmeninin bu yaşta \\
& çocuğun ihtiyaç duyduğu bireysel ilgi, sevgi, \\
& şefkat ve sabrı gösterebileceğine \\
& inanmıyorum»
\end{tabular}

Bu kategoride, eğitimci adayları yetişkinçocuk oranının yüksek olması nedeni ile, bire-bir iletişime ve ilgiye ihtiyaç duyan bebeklerin bu ihtiyaçlarının karşılanmayacağını iddia etmiştir.

\begin{tabular}{lll}
\hline $\begin{array}{l}\text { Düşük kurum } \\
\text { kalitesi }\end{array}$ & $\begin{array}{l}\text { «Bence iyi eğitim veren bir kuruma gitmeliler, } \\
\text { maalesef Türkiye'de böyle kurumlar kıt. O } \\
\text { nedenle annenin yanında daha iyi ilerlerler } \\
\text { diye düşünüyorum» }\end{array}$ & $\begin{array}{l}\text { Bu kategoride, katılımcılar ülkemizde 0-36 } \\
\text { aylık dönemdeki çocuklara eğitim verecek } \\
\text { kaliteli kurumların azlığına vurgu } \\
\text { yapmışlarıdır. }\end{array}$ \\
\hline $\begin{array}{l}\text { Çocuğun öz- } \\
\text { bakımını } \\
\text { sağlayamaması }\end{array}$ & $\begin{array}{l}\text { «Gitmemeli. Çocukların 3 yaşından sonra } \\
\text { okul öncesi eğitime gitmeleri gerektiğini } \\
\text { düşünüyorum. Çünkü çocuklar genellikle 3 } \\
\text { yasında tuvalve diğerlerisşkanlığını }\end{array}$ & $\begin{array}{l}\text { Bu kategoride, katılımcılar bebeklerin öz- } \\
\text { bakımlarını sağlayamadıklarını (özellikle } \\
\text { tuvalet eğitimi) ve bu nedenle bu süreçte } \\
\text { kazanitime dahil olmamaları gerektiğine vurgu }\end{array}$ \\
& & $\begin{array}{l}\text { yapmışlardır. } \\
\end{array}$
\end{tabular}

\section{EVET}

\begin{tabular}{|c|c|c|}
\hline Kategori & Örnek Kod & Kategori tanımı \\
\hline $\begin{array}{l}\text { Kaliteli zaman } \\
\text { imkânı }\end{array}$ & $\begin{array}{l}\text { "Bence gitmeliler, anne ve babalar } \\
\text { çocuklarıly vakit geçirseler bile kaliteli vakit } \\
\text { geçirme olasıllikları daha düşük. Bu nedenle } \\
\text { bu işi profesyonellere birakmak gerekir." }\end{array}$ & $\begin{array}{l}\text { Bu kategoride, katılımcıların eğitim } \\
\text { ortamında bebeklere daha kaliteli zaman } \\
\text { imkânı sunulacağını düşündükleri } \\
\text { görülmektedir. }\end{array}$ \\
\hline & $\begin{array}{l}\text { "Veliler çok da bilinçli değil, bebeklerle nasıl } \\
\text { vakit geçireceklerini çok iyi bilmiyorlar. } \\
\text { Kurumlarda bebekler daha kaliteli zaman } \\
\text { geçirecektir." }\end{array}$ & \\
\hline
\end{tabular}




\begin{tabular}{|c|c|c|}
\hline \multirow[t]{2}{*}{ Sosyalleşme } & $\begin{array}{l}\text { "Mümkünse gitmeliler, bu yaşlarda daha çok } \\
\text { insan ve yaşıtlarıyla karşılaşmalı, } \\
\text { sosyalleşmelidir." }\end{array}$ & $\begin{array}{l}\text { Bu kategoride, bebeklerin etkileşime gireceği } \\
\text { yetişkin sayısının fazla olmasıının } \\
\text { sosyalleşmeyi destekleyeceği fikri öne } \\
\text { sürülmektedir. }\end{array}$ \\
\hline & $\begin{array}{l}\text { "Evet gitmeliler, özellikle çalışan annelerin } \\
\text { bebeklerine yaşl olan anneanne, babaanneleri } \\
\text { bakıyor. Onlar da çocuğa yetemiyor. Çocuk } \\
\text { akranlarıla vakit geçirip sosyalleşmeli" }\end{array}$ & \\
\hline $\begin{array}{l}\text { Gelişimin } \\
\text { desteklenmesi }\end{array}$ & $\begin{array}{l}\text { "Çocuk doğar doğmaz eğitime tabi tutulursa } \\
\text { gelişim ve öğrenmesi hızlanacaktır.3 yaş } \\
\text { eğitime başlamak için çok geç. Çocuk } 0-3 \text { yaş } \\
\text { aralığında maksimum potansiyele sahip } \\
\text { bence. Bu potansiyel eğitimle desteklenmeli." }\end{array}$ & $\begin{array}{l}\text { Bu dönemde verilecek eğitimin, sahip } \\
\text { olunan potansiyeli destekleyeceği öne } \\
\text { sürülmektedir. }\end{array}$ \\
\hline Kaliteli Eğitim & $\begin{array}{l}\text { "Evet gitmeli, sosyal, duygusal, psikomotor } \\
\text { yönden gelişimleri uzman kişiler, öğretmenler } \\
\text { rehberliğinde sağlanmalı." }\end{array}$ & $\begin{array}{l}\text { Bu dönemde bebeklerin alanında uzman } \\
\text { kişiler tarafindan desteklenmesi gerektiğine } \\
\text { vurgu yapılmaktadır. }\end{array}$ \\
\hline
\end{tabular}

Tablo 2'de görüldüğü üzere, katılımcıların \%67,5’inin ( $\mathrm{n}=81$ ) olumsuz yanıt verdiği bu soruda öne sürülen nedenler dört farklı kategoride toplanmıştır. Bunlar, (1) Aileye duyulan ihtiyaç, (2) kurumda ilgi yetersizliği, (3) düşük kurum kalitesi ve (4) çocuğun öz-bakımını sağlayamaması. Bu kategorilere ilişkin kodlar incelediğinde, iki önemli nokta göze çarpmaktadır; katılımcıların çok büyük bir kısmı (1) 0-36 aylık dönemdeki çocukların eğitim sistemine katılımlarına yönelik yaygın olan toplumsal inanışları taşımaktadır ve (2) 0-36 aylık çocuklar için ülkemizde sunulan eğitim hizmetlerine güven duymamaktadırlar.

Yalnızca 39 katılımcı 0-36 aylık dönemde bebeklerin eğitim hayatına dahil olması gerektiğini düşündüğünü belirtmiştir. Bu görüşe sahip öğretmen adaylarının ifadelerinden ise dört farklı kategori ortaya çıkmıştır. Bunlar, (1) Kaliteli zaman imkanı, (2) Sosyalleşme, (3) Gelişimin desteklenmesi ve (4)kaliteli eğitim imkanı şeklindedir. Çalışmada elde edilen verilerin ve bulguların anlatıldığı ana bölümdür.

Yazılı görüşme formunda yer alan üçüncü soru, "Meslek hayatına başladığınızda, 0-36 aylık çocuklarla çalışmak ister misiniz? Neden” şeklindedir. Öğretmen adaylarının yarıdan fazlasının $(\% 59,1)$ bebeklik dönemindeki çocuklarla çalışmayı tercih etmediği, sadece \%40,9'unun bu soruya olumlu yanıt verdiği gözlemlenmiştir. Sorulara verilen yanıtların nedenleri analiz edildiğinde, Tablo 3’teki bilgilere ulaşılmıştır.

Tablo 3. 0-36 aylık çocuklarla çalışmaya yönelik katılımcı görüşleri

\begin{tabular}{lll}
\hline & & HAYIR \\
\hline Kategori & Örnek Kod & Kategori tanımı \\
\hline
\end{tabular}




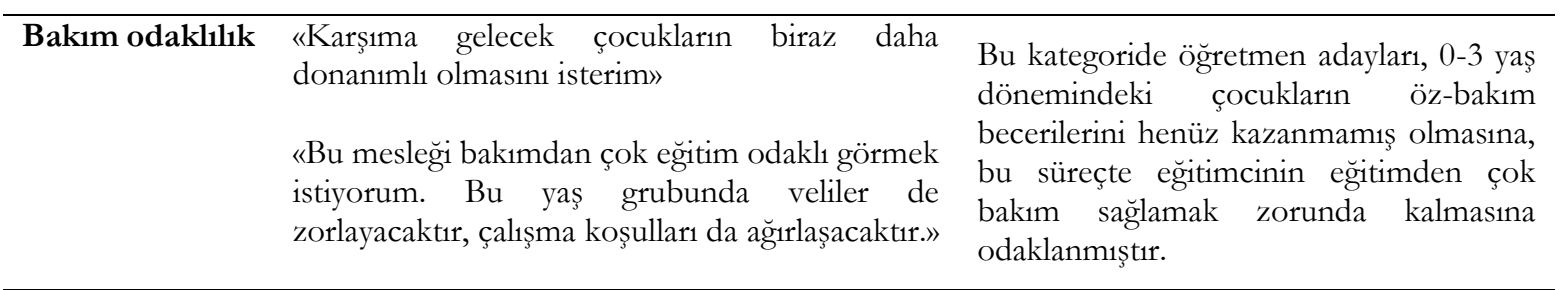

\begin{tabular}{ll}
\hline Donanım & «llk yıllarda bu yaş grubuyla çalışmaktan \\
yetersizliği & çekinirim. Çünkü okulda aldığım eğitimin daha \\
& çok 3-6 yaşa yönelik olduğunu düşünüyorum»
\end{tabular}

$\mathrm{Bu}$ kategoride öğretmen adayları, üniversite eğitimleri süresince aldıkları eğitimin 36-66 aylık çocuklara yönelik olmasına odaklanmıştır.

\begin{tabular}{ll}
\hline $\begin{array}{l}\text { Deneyim } \\
\text { yetersizliği }\end{array}$ & $\begin{array}{l}\text { «Staj okullarında daha büyük yaş gruplarıyla } \\
\text { çalışı̆̆ım için 0-3 yaş grubunda pratikte } \\
\text { yetersizliklerim var» }\end{array}$ \\
& "Bu yaş grubundaki çocuklarla hiç deneyimim \\
& olmadı. Onlarla bir günü nasıl geçirebileceğime \\
dair hiçbir tecrübem yok." & \\
\hline Yetersizlik & «Hayır. Çalışmak istemem. Bu konuda kendimi \\
Kaygısı & yeterli hissetmiyorum. Aslında onlara eğitim \\
& verebilirim fakat bu durum ne kadar sağlıklı olur? \\
& 0-3 yaş grubu ile çalışmak diğer yaş gruplarına \\
& göre daha çok özveri gerektiriyor.» \\
& «Ona annesinin vereceği ilgi, şefkat ve sevgiyi ne \\
& kadar çabalarsam çabalayayım verebileceğime \\
& inanmıyorum»
\end{tabular}

$\mathrm{Bu}$ kategoride öğretmen adayları öğretmenlik uygulaması derslerinde ve diğer uygulamalı derslerde 0-36 aylık çocuklarla çalışma firsatlarının olmadığına vurgu yapmiştır.

\begin{tabular}{lll}
\hline $\begin{array}{l}\text { Düşük Mesleki } \\
\text { Doyum }\end{array}$ & $\begin{array}{l}\text { «...bakıc1lı yapabilecek isteğim olduğunu } \\
\text { düşunmüyorum» }\end{array}$ &
\end{tabular}

«Ben daha çok öğretici etkinlikler yapmaktan hoşlanıyorum. 0-3 yaş eğitim odaklı olduğu için sahip olacağım pozisyonun beni akademik olarak tatmin edeceğini sanmiyorum»
$\mathrm{Bu}$ kategoride öğretmen adayları, toplumun 0-3 yaş grubu öğretmenlerini "bakıc1" olarak gördüğ̈ne, bu yaş grubu ile yapılacak etkinliklerin "sinırlı" olduğuna vurgu yapmıştır.

\section{EVET}

\begin{tabular}{ll}
\hline $\begin{array}{l}\text { Profesyonel } \\
\text { gelişim }\end{array}$ & $\begin{array}{l}\text { «İsterim çünkü stajlarda hep } 5 \text { yaşla çalıştım. } 0-3 \\
\text { yaş grubunun gelişimini, yapabildiklerini görmek } \\
\text { benim için avantajlı olur» }\end{array}$ \\
& "İsterim tabi ki, bu yaş grubu da bizim \\
& $\begin{array}{l}\text { mesleğimizin bir parçası. Onları da tanımak beni } \\
\text { daha iyi bir öğretmen yapacaktır." }\end{array}$
\end{tabular}

Geçmiş

Deneyimler
«Ben part-time olarak bu yaş grubu ile çalıştım, pek sıkıntı yaşamadım, bundan dolayı bu yaş grubuyla çalışmayı düşünürüm»

"Benim 2 yaşında bir kuzenim var. Onunla çok iyi vakit geçirdiğim için, bu yaş grubundaki diğer çocuklarla da birlikte çalışırsam zorluk yaşayacağımı düşünmüyorum
$\mathrm{Bu}$ kategoride öğretmen adayları, 0-36 aylık çocukların ihtiyaç duyduğu "anne" ilgi ve şefkatini verebilme konusunda yetersiz kalmaktan kayg1 duyduklarını belirtmişlerdir.
Bu kategoride öğretmen adayları erken çocukluk döneminin 0-6 yaş grubunu içerdiği ve her yaşta deneyim kazanmanın mesleki gelişime katkı sağlayacağına odaklanmıştır.
$\mathrm{Bu}$ kategoride öğretmen adayları, öğretmenlik uygulamalarında 3 yaş grubu ile staj yapmalarının ya da bu yaş grubundaki çocuklarla etkileşimde olmanın önemine vurgu yapmıştır. 


\begin{tabular}{|c|c|c|}
\hline Mesleki doyum & $\begin{array}{l}\text { "Stajlarımda özellikle } 3 \text { yaş grubunda çalışmak } \\
\text { istedim. Onlarla çalışmak inanılmaz keyifli...» } \\
\text { «Evet isterim, çünkü sevgi ile yaklaşımın yoğun } \\
\text { olması ve beceri kazanımının yoğunluğu ilgimi } \\
\text { çekiyor» }\end{array}$ & $\begin{array}{l}\text { Bu kategoride öğretmen adayları, 0-36 } \\
\text { aylık çocukların daha hızlı öğrendiğine ve } \\
\text { bunun eğitimcide yaratacağı duygusal } \\
\text { tatminin daha yüksek olacağına } \\
\text { odaklanmıştır. }\end{array}$ \\
\hline $\begin{array}{l}\text { Profesyonel } \\
\text { gelişim }\end{array}$ & $\begin{array}{l}\text { «İsterim çünkü stajlarda hep } 5 \text { yaşla çalıştım. 0-3 } \\
\text { yaş grubunun gelişiminin, yapabildiklerini görmek } \\
\text { benim için avantajlı olur» } \\
\text { "İsterim tabi ki, bu yaş grubu da bizim } \\
\text { mesleğimizin bir parçası. Onları da tanımak beni } \\
\text { daha iyi bir öğretmen yapacaktır." }\end{array}$ & $\begin{array}{l}\text { Bu kategoride öğretmen adayları } \\
\text { erken çocukluk döneminin } 0-6 \text { yaş } \\
\text { grubunu içerdiği ve her yaşta deneyim } \\
\text { kazanmanın mesleki gelişime katk1 } \\
\text { sağlayacağına odaklanmıştır. }\end{array}$ \\
\hline
\end{tabular}

Tablo 3’tede görüldüğü gibi, katılımcıların bu soruya olumsuz yanıt verme nedenleri (1) bakım odaklılık, (2) donanım yetersizliği (3)deneyim yetersizliği, (4) yetersizlik kaygısı ve (5) düşük mesleki doyum olmak üzere beş farklı kategoride toplanmıştır; 0-36 aylık çocuklarla çalışmak istediğini beyan eden katılımcıların cevaplarına dair yapılan analizlerde eğitimci adaylarının bu yaş grubu ile çalışmak isteme nedenlerinin üç kategoride toplandığı sonucuna ulaşılmıştır. Bunlar, (1) profesyonel gelişim, (2) geçmiş deneyimler ve (3) mesleki doyum şeklindedir. Bu kategorilerin içerikleri incelendiğinde, bebeklik dönemindeki çocuklarla çalışmak isteyen katılımcıların bu dönemde ki çocuklarla geçmiş bir deneyime sahip olduğu, bu dönem çocuğunun gelişimsel özelliklerinin farkında olduğu ve mesleki gelişimi için her yaş grubundaki çocuklarla çalışması gerektiğine inandığ1 ortaya çıkmıştır.

Yaz1lı görüşme formunda yer alan bir diğer soru, "0-36 aylık çocuklarla çalışabilecek donanıma sahip olduğunuzu düşünüyor musunuz? Neden?” şeklindedir. Katılımcıların yarıdan fazlası 0-36 aylık çocuklarla çalışmak için yeterli donanıma sahip olmadıklarını belirtmişlerdir. Bu katılımcıların öne sürdügü tek neden, üniversite eğitimleri süresince aldıkları derslerin neredeyse hepsinde ve yaptıkları uygulamalarda 36-66 aylık çocuklara odaklanılmış olmasıdır. Katılımcıların \%19’u ise teorik açıdan bu yaş grubunun özelliklerine hâkim olduğunu ancak pratik açıdan kendilerini yeterli hissetmediklerini belirtmiştir. Diğer taraftan, katılımcıların sadece \%26's1 0-36 aylık çocuklarla çalışabilecek donanıma sahip olduğuna inandığını beyan etmiştir. Bu soruya olumlu yanıt veren katılımcılar üniversite eğitimleri süresince aldıkları eğitimin 0-6 yaş grubuna yönelik olduğunu ve 036 aylık çocukların da gelişimsel özelliklerini bildiklerini belirtmiştir.

Yaz1lı görüşme formunda yer alan son soru, "0-36 aylık çocuklarla çalışmayı, 36-66 aylık çocuklarla çalışmayla karşılaştırdığınızda, sizce avantajlı ve dezavantajlı durumlar neler olur?” şeklindedir. Katılımcıların \%90’1 0-3 yaş gurubu ile çalışmanın, 3-6 yaş grubu ile çalışmaktan daha avantajlı bir 
yönü olmadığını belirtmiştir. Tablo 4’te görüldüğü gibi çalışmaya katılan öğretmen adaylarının yanıtları tematik kodlama yöntemi ile analiz edildiğinde 0-36 aylık çocuklarla çalışmanın, 36-66 aylık çocuklarla çalısmaya göre avantajları 5 kategoride (eğitim içeriği, öğrenme kapasitesi, sınıf hakimiyeti, mesleki gelişim ve mesleki doyum) dezavantajları ise altı kategoride (iş yükü, eğitim içeriği, gelişimsel yetersizlikler, sınıf hakimiyeti, düşük mesleki doyum ve toplumsal algılar) toplanmıştır. Bebeklik dönemindeki çocuklarla çalışmanın, 36-66 aylık çocuklarla çalışmaya karşın avantajlı olduğunu düşünen katılımcıların yanıtlarından (1) teknik, (2) gelişimsel ve (3) duygusal avantajlar olmak üzere üç tema ortaya çıkarmıştır. Teknik avantajlar, eğitim içeriğinin daha basit olması, çocukların öğrenebilecekleri çok daha fazla kavram olması, etkinliklerin kısa ve basit olması, yetişkin/çocuk oranının azlığından ve yaş grubunun küçük olmasından dolayı sınıf hakimiyetinin kolay sağlanmasıdır. Gelişimsel avantajlar ise hem eğitimcinin profesyonel gelişimi hem de çocuğun gelişiminin hızlı olmasından kaynaklanan yüksek öğrenme kapasitesidir. Son olarak ortaya çıkan duygusal avantaj ise eğitimcinin mesleğinin gereklerini yerine getirmede, örneğin gelissimi gözlemlemek ya da gelişime katkı sunmak, daha fazla imkanının olmasıdır.

Dezavantajlara yönelik verilen yanıtların ortaya çıkardığı kategoriler ise, iş yükünün fazla olmasına, eğitim içeriğinin daha yoğun olmasına, bu dönemde çocukların gelişimsel bazı yetersizliklerinin iletişim kurma, tuvalet eğitimini almamış olma vb.- eğitim sürecini olumsuz etkileyeceğine, sınıf hakimiyetini kurmanın 0-36 aylık çocukların gelişimsel özelliklerinden dolayı daha zor olacağına, bu dönemdeki çocuklarla çalışırken yetersizlik hissinin yaşanabileceğine ve toplumun bu yaş grubu ile çalışanları eğitimci olarak algılamayacağına vurgu yapmaktadır. Ortaya çıkan bu kategorilerde teknik dezavantajlar (eğitim içeriği, iş yükü, sınıf hakimiyeti), gelişimsel dezavantajlar (gelişimsel yetersizlikler) ve duygusal dezavantajlar (düşük mesleki doyum ve toplumsal alg1) temaları altında gruplandırılmıştır.

Tablo 4. 0-36 aylık çocuklarla çalışmanın avantajları ve dezavantajlarına ilişkin katılımcı görüşleri

\section{AVANTAJLAR}

\begin{tabular}{|c|c|c|}
\hline Kategoriler & Örnek Kod & Kategorinin tanımı \\
\hline $\begin{array}{c}\text { Teknik } \\
\text { Avantajlar }\end{array}$ & $\begin{array}{l}\text { Eğitim İçeriği } \\
\text { "Avantaj1, bu yaş grubu çocuklara } \\
\text { öğretmemiz gereken konuların çok olması, } \\
\text { öğreteceğimiz kavram ve konuların daha } \\
\text { basit olması olabilir" } \\
\text { "36 aylık çocuklar için etkinlik hazırlamak } \\
\text { daha kolay olabilir. Dikkat süreleri kısa } \\
\text { olduğu için daha kısa etkinlikler hazırlanır, } \\
\text { etkinlik içeriği de daha basit olur." }\end{array}$ & $\begin{array}{l}\text { Bu kategoride öğretmen adayları, 0-36 aylık çocuklar için } \\
\text { hazırlanacak programlarda konu ve kavramların daha basit } \\
\text { olduğuna, etkinliklerin daha kısa ve basit olduğuna ve } \\
\text { öğretilebilecek çok daha fazla konu ve kavram olduğuna } \\
\text { vurgu yapmistır. }\end{array}$ \\
\hline
\end{tabular}




\begin{tabular}{|c|c|c|}
\hline & $\begin{array}{l}\text { Sınıf hakimiyeti } \\
\text { "Küçük çocuklar bizi daha çok dinler. } \\
\text { Sınıfta otorite kurmamız daha kolay olur." } \\
\text { "Bu yaş grubunda çocuk sayısı az olur, o } \\
\text { nedenle sınıf hakimiyeti çok daha rahat bir } \\
\text { şekilde kurulur diye düşünüyorum." }\end{array}$ & $\begin{array}{l}\text { Bu kategoride öğretmen adayları, 0-36 aylık dönemde } \\
\text { çocuklarla çalışırken sınıf hakimiyeti kurmada daha başarılı } \\
\text { olacaklarına, çocukların çok daha fazla öğretmen sözü } \\
\text { dinleyeceğine vurgu yapmıştır. }\end{array}$ \\
\hline \multirow[t]{2}{*}{$\begin{array}{l}\text { Gelişimsel } \\
\text { Avantajlar }\end{array}$} & $\begin{array}{l}\text { Öğrenme kapasitesi } \\
\text { "Bu yaş grubuyla çalışmanın en büyük } \\
\text { avantajı çocukların öğreteceğimiz basit } \\
\text { kavramları çok çabuk öğrenmesidir diye } \\
\text { düşünüyorum.” } \\
\text { "Bu yaş grubundaki çocukların bilişsel } \\
\text { kapasitesi çok yüksek. Öğretmek } \\
\text { istediğimiz her şeyi büyük çocuklardan } \\
\text { daha çabuk öğreneceklerdir.” }\end{array}$ & $\begin{array}{l}\text { Bu kategoride öğretmen adayları, 0-36 aylık dönemde } \\
\text { çocukların çok daha hızlı ögrenebileceklerine vurgu } \\
\text { yapmıştır. }\end{array}$ \\
\hline & $\begin{array}{l}\text { Mesleki gelişim } \\
\text { "En büyük avantajı mesleki deneyim } \\
\text { kazanmam olurdu." } \\
\text { "Bu yaş grubuyla çalıştıktan sonra büyük } \\
\text { yaştaki çocuklarla çalışmak çok daha kolay } \\
\text { olur, diye düşünüyorum." }\end{array}$ & $\begin{array}{l}\text { Bu kategoride öğretmen adayları, 0-36 aylık dönemdeki } \\
\text { çocuklarla çalışmanın mesleki gelişime çok önemli bir katkı } \\
\text { sağlayacağına vurgu yapmıştır. }\end{array}$ \\
\hline $\begin{array}{l}\text { Duygusal } \\
\text { Avantajlar }\end{array}$ & $\begin{array}{l}\text { Mesleki doyum } \\
\text { Bu dönemde çocuklar her gün yeni bir } \\
\text { beceri geliştirip, yeni şeyler öğreniyorlar. } \\
\text { Bu nedenle onların gelişimlerini } \\
\text { gözlemlemek daha kolay olur.” } \\
\text { "0-36 aylık çocuklarla çalışmanın en büyük } \\
\text { avantajı onlarla hayata yeni başladıkları bu } \\
\text { dönemde birlikte olmak, öğrendikleri her } \\
\text { şeyde benimde katkımın olacağını bilmek } \\
\text { olurdu. Bu, çok keyifli bir şey olsa gerek.” }\end{array}$ & $\begin{array}{l}\text { Bu kategoride öğretmen adayları, 0-36 aylık çocuklarla } \\
\text { çalışan eğitimcilerin çocukların gelişimini daha rahat } \\
\text { gözlemleyebileceğine; çocuğun gelişimine birebir katkı } \\
\text { sağlama şansının olacağına ve 0-3 yaş dönemindeki } \\
\text { çocuklarla çalışmanın daha eğlenceli ve keyifli olacağına } \\
\text { vurgu yapmıştır. }\end{array}$ \\
\hline \multicolumn{3}{|c|}{ DEZAVANTAJLAR } \\
\hline $\begin{array}{c}\text { Teknik } \\
\text { Dezavantajlar }\end{array}$ & $\begin{array}{l}\text { İş yükü } \\
\text { “Bu yaş grubuyla çalışmak bence } \\
\text { dezavantajlı olur. Bu yaş grubundaki } \\
\text { çocuklara enerjimizin yetmesi çok zor olur. } \\
\text { Çok çabalamak gerekir. Çok daha } \\
\text { yorucudur." } \\
\text { "Her çocukla birebir ilgilenmeniz gerek. } \\
\text { Bu büyük çocuklarda da böyle ama küçük } \\
\text { çocuklarda bu daha önemli. Bu çok yorucu } \\
\text { olur” } \\
\text { Eğitim içeriği } \\
\text { "Durmadan benzer ya da aynı etkinlikleri } \\
\text { yapmak zorundayız ki çocuklar daha kalıcı } \\
\text { bir şekilde öğrensinler. Bu bence çok } \\
\text { sıkıcı." } \\
\text { "Ben akademik etkinlikler yapmaktan } \\
\text { hoşlanıyorum. Bu yaş grubu ile böyle } \\
\text { etkinlikler yapamam.” } \\
\text { "Bu yaş grubuyla hazırlanacak etkinlikleri } \\
\text { uygulamak çok zor olur." }\end{array}$ & $\begin{array}{l}\text { Bu kategoride öğretmen adayları, 0-36 aylık çocuklarla } \\
\text { çalışmanın daha yıpratıcı olacağına, kurumlarda çocuk } \\
\text { sayısının gereğinden fazla olacağına, eğitimcinin bu yaş } \\
\text { grubu ile çalışırken daha fazla çaba harcaması gerektiğine ve } \\
\text { 0-36 aylık çocuklarla çalışmanın eğitimden çok bakım odaklı } \\
\text { bir süreç olduğuna vurgu yapmıştır. }\end{array}$ \\
\hline
\end{tabular}




\begin{tabular}{|c|c|c|}
\hline & $\begin{array}{l}\text { Sinıf Hakimiyeti } \\
\text { "Düşünsenize } 10 \text { tane bir buçuk yaşında } \\
\text { çocuk olsa bir sınıfta, nasıl lafınızı } \\
\text { dinleteceksiniz? Sınıfta bir etkinlik yapmak } \\
\text { neredeyse imkânsız olacaktır." } \\
\text { "Dikkat süreleri kısa ve birbirlerine zarar } \\
\text { vermeye meyilliler. Bu nedenle sınıf } \\
\text { hakimiyetini kurmak çok zor olurdu, en } \\
\text { büyük dezavantajı bu bence.” } \\
\text { "Bu yaş grubunda beş çocukla aynı sınıfta } \\
\text { nasıl bir etkinlik yapılabilir ki? En zor yanı } \\
\text { bu çocuklarla sınıf hakimiyetini kurmak } \\
\text { olurdu." }\end{array}$ & $\begin{array}{l}\text { Bu kategoride öğretmen adayları, 0-36 aylık çocukların } \\
\text { dikkat sürelerinin kısa olmasına, daha hareketli olmalarına, } \\
\text { yönergeleri almada sıkıntı yaşanabileceğine, birbirlerine } \\
\text { zarar verebileceklerine, güveliğin ön planda olmasın ve } \\
\text { otorite kurmanın zor olmasına vurgu yapmışlardır. }\end{array}$ \\
\hline $\begin{array}{c}\text { Gelişimsel } \\
\text { Dezavantajlar }\end{array}$ & $\begin{array}{l}\text { Çocukların Gelişimsel Yetersizlikleri } \\
\text { "Konuşamayan çocuklarla nasıl etkili bir } \\
\text { eğitim süreci yapılabilir? Bence 0-3 yaş } \\
\text { aralığındaki çocuklarla çalışmanın en } \\
\text { dezavantajlı kısmı budur; } \\
\text { konuşamamaları." } \\
\text { "Tuvalet eğitimini almamış oluyorlar, } \\
\text { çocukların altını değiştirmek istemem } \\
\text { açıkçası." } \\
\text { "Dezavantaj1, gelişimsel özelliklerinden } \\
\text { dolayı bu yaş grubundaki çocuklarla } \\
\text { yapılabilecek etkinliklerin kısıtlı olması." }\end{array}$ & $\begin{array}{l}\text { Bu kategoride öğretmen adayları 0-36 aylık çocukların dil, } \\
\text { öz-bakım ve fiziksel gelişim özelliklerinin eğitim sürecini } \\
\text { negatif etkileyeceğine vurgu yapmıştır. }\end{array}$ \\
\hline \multirow{2}{*}{$\begin{array}{c}\text { Duygusal } \\
\text { Dezavantajlar }\end{array}$} & $\begin{array}{l}\text { Düşük Mesleki Doyun } \\
\text { "Ben başı sonu belli olmayan bir etkinlik } \\
\text { yaptığımda kendimi çok da eğitimci gibi } \\
\text { hissedeceğimi düşünmüyorum." } \\
\text { "Çok büyük sorumluluk. Çocuklara karşı } \\
\text { bire bir ilgi gösteremezseniz, onlara ihtiyacı } \\
\text { olan sevgiyi veremezseniz kendinizi çok } \\
\text { kötü hissedebilirsiniz." }\end{array}$ & $\begin{array}{l}\text { Bu kategoride öğretmen adayları, } 0-36 \text { aylık çocuklarla } \\
\text { çalışmanın öğretmende yetersizlik hissi yaratacağına, } \\
\text { yapılabileceklerin sınırlı olduğuna ve bu dönem çocuklarla } \\
\text { çalışmanın eğitimden çok bakımı gerektiren süreçleri } \\
\text { içerdiğine vurgu yapmıstır. }\end{array}$ \\
\hline & $\begin{array}{l}\text { Olumsuz Toplumsal Yargılar } \\
\text { “Anaokulu öğretmeni olacağım deyince bile } \\
\text { insanlar milletin çocuğuna mı bakacaksın } \\
\text { diyorlar. Bebeklerle çalışsam herhalde } \\
\text { tamamen bakıcı muamelesi görürüm.” } \\
\text { "Ülkemizde mesleğimizin değeri bilinmiyor } \\
\text { zaten, bebeklerle çalışsak bizi öğretmen } \\
\text { olarak görmez kimse.” }\end{array}$ & $\begin{array}{l}\text { Bu kategoride öğretmen adayları, } 0-36 \text { aylık çocuklarla } \\
\text { çalışan eğitimcilerin veliler ve toplum tarafından sayg1 } \\
\text { görmeyeceğine, onlara bakıcı olarak bakılacağına vurgu } \\
\text { yapmışlardır. }\end{array}$ \\
\hline
\end{tabular}

\section{Bölüm II}

\section{Yıllar Arasında bir Karşılaştırma}

Mevcut çalışmanın temel amaçlarından biri okul öncesi öğretmen adaylarının bebeklik döneminde kurum temelli eğitime ilişkin görülerini betimlemek iken, bir diğer amacı ise bebeklik döneminde sunulan kurum temelli eğitim sürecini pozitif etkileyebilecek birçok sürecin yaşandığ1 2008 ve 2015 yılları arasında son sınıf öğrencisi olan öğretmen adaylarının bebeklik döneminde eğitime ilişkin görüşlerinde bir değişimin gerçekleşip gerçekleşmediğini ortaya koymaktır. Bu bölümde çalışma 
verisinin toplandığı yıllar arasında öğretmen adaylarının sorulara verdikleri cevapların yüzdeler üzerinden bir karşılaştırması yapılacaktır. Tablo 5 karşılaştırmaya yönelik bir özet sunmaktadır.

Tablo 5, 2008 yllından 2015 yılına kadar ki yedi yıllık süreçte, öğretmen adaylarının bebeklik döneminde eğitime ilişkin düşüncelerinin çok da fazla değişmediğini göstermektedir. Sorulara verilen yanıtlar incelendiğinde, çalışmaya katılan tüm öğretmen adaylarının çalışmaya katılma yıllarından bağımsız olarak 0-36 aylık dönemin çocuğun hayatından önemli bir yere sahip olduğunu belirttikleri gözlemlenmektedir.

Tablo 5: Yıllar arasında katılımcıların görüşlerindeki değişim

\begin{tabular}{|c|c|c|c|c|c|c|c|c|c|c|c|}
\hline & \multicolumn{2}{|c|}{$\begin{array}{l}\text { 0-36 aylik } \\
\text { dönem sizce } \\
\text { önemli midir? }\end{array}$} & \multicolumn{2}{|c|}{$\begin{array}{l}\text { 0-36 aylik } \\
\text { dönemdeki } \\
\text { çocuklar okul } \\
\text { öncesi eğitimi } \\
\text { almalı midır? }\end{array}$} & \multicolumn{2}{|c|}{$\begin{array}{l}\text { 0-36 aylık } \\
\text { çocuklarla } \\
\text { çalişmak ister } \\
\text { misiniz? }\end{array}$} & \multicolumn{3}{|c|}{$\begin{array}{l}\text { 0-36 aylik çocuklarla } \\
\text { çalısabilecek donanıma } \\
\text { sahip misiniz? }\end{array}$} & \multicolumn{2}{|c|}{$\begin{array}{l}\text { 0-36 aylık çocuklarla çalışmanın, } \\
\text { 36-66 aylık çocuklarla çalışmaya } \\
\text { göre avantaj ve dezavantajları } \\
\text { nelerdir? }\end{array}$} \\
\hline & Evet & Hayır & Evet & Hayır & Evet & Hayır & Evet & $\begin{array}{l}\text { Teorik } \\
\text { olarak }\end{array}$ & Hayır & Avantajlıdır & Dezavantajlıdır \\
\hline & $\%$ & $\%$ & $\%$ & $\%$ & $\%$ & $\%$ & $\%$ & evet $\%$ & $\%$ & $\%$ & $\%$ \\
\hline $\begin{array}{l}2008 \\
(n=20)\end{array}$ & 100 & - & 35 & 65 & 50 & 50 & 25 & 15 & 60 & 10 & 90 \\
\hline $\begin{array}{l}2010 \\
(n=25)\end{array}$ & 100 & - & 32 & 68 & 44 & 56 & 24 & 24 & 52 & 12 & 88 \\
\hline $\begin{array}{l}2012 \\
(n=35)\end{array}$ & 100 & - & 34,3 & 65,7 & 42.8 & 57,2 & 28,5 & 22.8 & 48.5 & 8,6 & 91.4 \\
\hline $\begin{array}{l}2014 \\
(n=25)\end{array}$ & 100 & - & 28 & 72 & 36 & 64 & 24 & 20 & 52 & 12 & 88 \\
\hline $\begin{array}{l}2015 \\
(n=15)\end{array}$ & 100 & - & 33.3 & 76.7 & 26.7 & 73,3 & 20 & 6.7 & 73.3 & 13.3 & 86.7 \\
\hline
\end{tabular}

“0-36 aylık çocuklarla çalışabilecek donanıma sahip olduğunuzu düşünüyor musunuz?” sorusuna verilen yanıtlarda da yıllar arasında çok büyük bir farklılığa rastlanmamıştır. Tüm yıllarda katılımcıların yarıdan fazlası, aldıkları derslerin ve eğitimleri boyunca yaptıkları uygulamaların neredeyse hepsinin 36 aydan daha büyük çocuklara yönelik olduğuna vurgu yaparak, kendilerini 036 aylık çocuklarla çalışma konusunda donanımlı görmediklerini beyan etmişlerdir. Araştırmaya farklı yıllarda katılan öğretmen adaylarının çoğu 0-36 aylık çocuklarla çalışmanın 36-66 aylık çocuklarla çalışmaya oranla dezavantajlı bir durum olduğunu beyan etmişlerdir. Böyle düşünen eğitimci adaylarının oranının neredeyse verilerin toplandığı her yıl \%86'nın üzerinde olduğu saptanmıştır. 
TARTIŞMA

Mevcut çalışma iki temel amaç üzerine kurgulanmıştır. Bunlardan ilki okul öncesi öğretmen adaylarının bebeklik döneminde eğitime ilişkin görüşlerini betimlemek, ikincisi ise bebeklik döneminde eğitime ilişkin öğretmen adaylarının görüşlerini etkileyebilecek birçok gelişmenin yaşandığı 2008-2015 yılları arasında son sınıf okuyan öğretmen adaylarının bebeklik döneminde eğitime ilişkin görüşlerinde bir farklılık olup olmadığını ortaya koymaktır. Çalışmada katılımcıların beş açık uçlu soruya verdikleri yanttlar içerik analizi ve tematik kodlama yöntemlerinden faydalanılarak analiz edilmiştir. Katılımcılara sorulan ilk soru bebeklik döneminin önemine ilişkindir. Çalışmaya katılan tüm katılımcılar, bebeklik döneminin önemli olduğunu düşündüklerini beyan etmişlerdir. Bu düşüncelerinin nedenlerini daha çok gelişime vurgu yaparak açıklamışlardır. Soruya verilen yanıtlar incelendiğinde, öğretmen adaylarının 0-36 aylık dönemin önemine ilişkin farkındalık düzeylerinin oldukça yüksek olduğu fark edilmiştir.

Katılımcıların \%67,5’i bebeklik döneminde çocukların aileye duyulan ihtiyaç, kurumda ilgi yetersizliği, düşük kurum kalitesi ve çocuğun öz-bakımını sağlayamaması gibi nedenlerle kurum temelli eğitime dahil olmaması gerektiğini düşündüklerini belirtmişlerdir. Bu kategorilere ilişkin kodlar incelediğinde, iki önemli nokta göze çarpmaktadır; katılımcıların çok büyük bir kısmı (1) 036 aylık dönemdeki çocukların eğitim sistemine katılımlarına yönelik yaygın olan toplumsal inanışları taşımaktadır ve (2) 0-36 aylık çocuklar için ülkemizde sunulan eğitim hizmetlerine güven duymamaktadirlar

Ne yazık ki bu üzücü bir tablodur. Bu tablo bize, erken çocukluk dönemi için öğretmen yetiştiren üniversite programlarının öğretmen adaylarının bebeklik döneminde bakım ve eğitime ilişkin düşüncelerini etkilemediğini ve bir yıl sonra profesyonel meslek yaşantısına atılacak bu eğitimcilerin toplumun her kesiminde yaygın bir biçimde kabul gören "küçük çocuğa evde ve mümkünse anne tarafindan bakılmalıdır" algısına sahip olmalarının önüne geçmede son derece yetersiz kaldığını göstermektedir. Bu durum direkt olarak devlet politikaları ve erken çocukluk dönemine ilişkin sosyal politikalarla ilişkilidir. Daha öncede belirtildiği gibi, ülkemizde 0-36 aylık çocukların bakım ve eğitim hizmetlerini sunan kuramların Millî Eğitim Bakanlığı'na değil Aile ve Sosyal Politikalar Bakanlığı'na bağlı olması, bu sürecin eğitimden daha çok aileye ilişkin bir yardım süreci, bakıcılık gibi algılanmasına yol açmakta ve Millî Eğitim Bakanlığı bu konuda herhangi bir sorumluluk üstlenmemektedir. Benzer bir şekilde ülkemizde uygulanan doğum izni, süt izni, yarım gün çalışma izni ve büyükanneye bakım teşviki gibi bazı sosyal politikalar anne ve çocuk bağlanması açısından önemli bir role sahip olsa da "küçük çocukların bakımı ve eğitimi annesi tarafından, annenin çalıştı̆̆1 
durumlarda ise büyükanne tarafindan sağlanmalıdır” algısını daha da güçlendirmektedir. Ancak, Dünya Bankasının 2015 yılında hazırladığı raporda da belirtildiği gibi bu sosyal hakların birçoğunu kullanma fırsatı olmayan ve neredeyse doğum izni süresi bitmeden işe başlamak zorunda kalan annelerin yaşamını kolaylaştıracak ve çocuklarının bakımı ve eğitimini güvenilir ve kaliteli bir hizmet sunan kurumlara bırakmalarına destek olabilecek herhangi bir sosyal politika uygulaması yoktur. Bu bağlamda, çalışmaya katılmış olan eğitimci adaylarının çoğunluğunun da kadın olduğu ve gelecekte anne olacakları düşünüldüğünde, öne sürdükleri bu görüşleri gelecek çalışma hayatlarında nasıl bir tavır sergileyeceklerinin de bir göstergesi olabilir. Bu soruya olumlu yanıt verenler katılımcıların argümanlarında, karşıt argümanların tersine eğitim sistemine, eğitim sistemindeki öğretmenlere ve eğitim sürecine dair bir güven ve pozitif bakış açısının varlı̆̆ı gözlemlenmektedir. Bu katılımcıların daha çok gelişimsel bir bakış açısıyla bebeklerin eğitime dahil olmaları gerektiğini düşündükleri gözlemlenmiştir. Başka bir deyişle, bebeklik döneminde kurum temelli eğitimi olumlu değerlendiren katılımcılar, bu dönemde bebeklerin eğitim sistemine dahil olmalarını sadece gelişimin desteklenmesi bağlamında değerlendirmişlerdir. Verilen yanıtlarda, bebeklik döneminde eğitimin kadın istihdamını arttıracağı, çocuklar arasında fırsat eşitliğini yaratmada etkili olacağı, yani bebeklik döneminde sunulan kaliteli bir kurum temelli eğitimin erken çocukluk eğitiminin toplumsal amaçlarını gerçekleştirme noktasında önemli olduğuna dair bir gerekçelendirmeye rastlanmamıştır. Ek olarak, bu katılımcıların da ebeveynlere ve çocukların bakımını sağlayan diğer kişilere yönelik olumsuz bir algıya sahip oldukları gözlemlenmektedir. Diğer bir deyişle, bu katılımcılar da, aileyi çocukların bakımını sağlama ve gelişimini destekleme konusunda yetersiz görmektedirler ve bu nedenle çocukların 0-36 aylık dönemde eğitim hayatına dahil olması gerektiğini düşünmektedirler. Bu durum, bir yıl sonra profesyonel meslek hayatına atılacak katılımcıların aile ve eğitimci arasında bir hiyerarşi algıladığını, ailenin çocuğun bakımı ve eğitimi noktasında yetersiz olduğunu düşündüğunnü ve bir noktada aile eğitimci birlikteliğine ket vurabilecek bir algiya sahip olduğunu göstermektedir. Bu çalışmanın kapsamı dışında kalsa da bu bakış açısı üzerinde durulması gereken önemli bir konudur.

Çalışmada, öğretmen adaylarının bebeklik dönemindeki çocuklarla çalışmaya ilişkin görüşleri incelenmiştir. Çalışmaya katılan öğretmen adaylarının çok büyük bir kısmı bebeklik dönemindeki çocuklarla çalş̧mak istemediğini beyan etmiştir. Bu durumun sebeplerine analizler sonucunda ortaya çıkan kategorilerin (bakım odaklılık, donanım yetersizliği, deneyim yetersizliği, yetersizlik kaygısı ve düşük mesleki doyum) içeriklerinde iki temel problem olduğu gözlemlenmiştir. Bunlardan ilki, 0-36 aylık çocuklarla çalışma noktasında katılımcıların sahip olduğu düşük özyeterlilik algısıdır. Katılımcılar, kendilerini 0-36 aylık çocuklarla çalışmak için donanımsız, 
deneyimsiz ve kaygllı hissetmektedirler. Howes, Phillips ve Whitebook (1992) yaptıkları araştırmada yüksek eğitime sahip olmanın, bebeklik döneminde eğitim kalitesini yordayan en önemli değişken olduğunu ortaya çıkartmıştır. Bu çalışmaya katılan öğretmen adayları ise, kaliteli bir bebeklik dönemi eğitimi sunma noktasında kendilerine yeterince güvenmediklerini belirtmişlerdir. Ne yazık ki, kapsamı 0-6 yaş grubundaki çocukların gelişimi ve eğitimi olan dört yıllık lisans eğitimi, öğretmen adaylarının kendilerini 0-3 yaş aralığındaki çocuklarla çalışmaya karşın yeterli, donanımlı ve deneyimli hissetmelerini sağlayamamıştır. Katılımcılarında belirttiği gibi, bu durum öğretmen yetiştirme programının öğretmen adaylarını daha çok 36 aylık ve üzeri çocukların eğitimi ve gelişimini konusunda yetkin kıldığının bir göstergesi olarak kabul edilebilir ve programın misyonunu tam anlamıla yerine getiremiyor olması şeklinde yorumlanabilir.

Yapılan analizler sonucunda ortaya çıkan bir diğer önemli nokta ise, öğretmen adaylarının çocukların bakımından sorumlu olmak istememeleridir. Erken çocukluk eğitimi hizmetleri hangi yaş grubu çocuklara sağlanırsa sağlansın, içerisinde bakıma ilişkin süreçleri barındırmaktadır. Bakıma yönelik süreçler, bu yaş dönemindeki bir çocuk için en önemli eğitim imkanlarını sunmaktadır (Greenman veStonehouse, 1996). 0-36 aylık dönem ise bu durumun çok daha yoğun bir şekilde yaşandığı bir süreçtir. Bu süreçte eğitimin bakıma yönelik süreçlerde verildiği bile iddia edilebilir. Bu bağlamda 0-36 aylık bebeklerle çalışan eğitimciler için uluslararası alan yazınında “educarer" yani "bakım ve eğitimi bir arada sunan kimse" kavramı kullanılmaktadır (Greenman ve Stonehouse,1996). Ne yazık ki katılımcıların verdiği cevaplar incelendiğinde, bakıma odaklılık 0-36 aylık çocuklarla çalışmayı tercih etmeyenlerin öne sürdüğü temel nedenlerden biridir. Ancak bu noktada sadece öğretmen yetiştirme programlarını sorumlu tutmak çok da doğru değildir. Üzülerek belirtmek gerekir ki, ülkemizde erken çocukluk eğitiminin önemine dair toplumsal bilinç istenilen düzeye ulaştırılamamıştır. Var olan sosyal politikalar ve uygulamalar sonucunda öğretmenlik mesleği gün geçtikçe saygınlığını yitirmekte, eğitim parayla satın alınan ve müşteri memnuniyeti sağlamak zorunda bırakılan özel bir sektöre dönüştürülmektedir. Bu bağlamda, henüz öz-bakımını sağlama konusunda yetkinleşmemiş ve yetişkinlerin desteğine daha fazla ihtiyaç duyan (Bieth, Penny, Bulman ve Robinson, 2005; Brownlee ve diğerleri, 2007) bireylerin eğitimini kapsayan okul öncesi eğitim süreci ve bu eğitimi sunan öğretmenler çalışan ve çocuklarının bakımını sağlamada zorlanan ebeveynlerin yerine geçen "bakıcılar" olarak algılanmaktadır. Ek olarak, ülkemizde yaygın olarak karşımıza çıkan bu algıyı ortadan kaldıracak, genelde erken çocukluk eğitiminin ve özelde bebeklik döneminde sunulan eğitim hizmetlerinin önemine dair bilinç düzeyini yükseltecek herhangi bir sosyal politika mevcut değildir. Bunu sonucu, eğitim düzeyi yüksek okul öncesi öğretmenlerinin, bebeklik döneminde eğitimi eğitim düzeyi daha düşük bireylere bırakması, alanda çalışmaya istekli 
olmamasıdır. Bu durum ise, ülkemizde sunulan ve sunulacak olan bebeklik dönemi eğitiminin kalitesinin düşük olacağı şeklinde yorumlanabilir. Yapılan araştırmalar, bebeklik dönemindeki çocukların kalitesiz eğitimciler ve uygun olmayan koşullardaki eğitim ortamlarından, ileriki yaşlara oranla çok daha olumsuz etkilendiğini göstermiştir (Karp,2006; Whitebook,2003). Bu bağlamda değerlendirildiğinde, üniversiteden mezun olmak üzere olan öğretmen adaylarının 0-36 aylık çocuklarla çalışmak istememesi önemsenmesi gereken ve kaygı verici bir durumdur.

Çalışmaya katılan öğretmen adaylarından bebeklik dönemindeki çocuklarla çalışmak istediğini beyan edenlerin bu dönemde ki çocuklarla geçmiş bir deneyime sahip olduğu, bu dönem çocuğunun gelişimsel özelliklerinin farkında olduğu ve mesleki gelişimi için her yaş grubundaki çocuklarla çalışması gerektiğine inandığı gözlemlenmiştir. Bu bulgular, daha önce yapılan çalışmalarla tutarlılık göstermektedir. Örneğin, Brownlee, Berthelsen ve Segaran (2007)'nın kurum müdürleri ve öğretmenlerle gerçekleştirdikleri çalş̧mada, her iki grubunda bebeklik döneminde iyi bir eğitim sunmanın en önemli gerekliliklerinden birinin bebeklerle ilgili uygulamalı deneyimlere sahip olmak olduğunu belirtmiştir. Bu durum, lisans eğitimine eklenecek bebeklik dönemi çocuklarına yönelik uygulama derslerinin arttırılması ihtiyacına vurgu yapmaktadır. Bebeklik dönemindeki çocuklarla bir araya gelme şansı bulmak, bir öğretmen adayının bu yaş grubundaki çocukları daha yakından gözlemlemesine olanak tanıyacaktır. Olumlu ve uygulamalı deneyimler, öğretmen adayının bebeklerle çalş̧maya ilişkin sahip olduğu olumsuz düşünceleri ve düşük öz-yeterlilik algısını değiştirebilir. Her ne kadar, bebeklik dönemindeki çocuklarla çalışığını beyan eden katılımcılar yalnızca 3 yaş grubu ile çalışmış olsalar da bu deneyimin onlarda bebeklik dönemine ilişkin olumlu bir bakış açısıyla sonuçlandığı ortadadır. Bu bağlamda, olumlu uygulama deneyimlerinin öğretmen adaylarında var olan "bebek grubu ile çalıştı̆̆ımda, mesleki doyum elde edemem” ya da "bebek grubu ile çalıştığımda kendimi eğitimci gibi hissedemem” düşüncelerini değiştireceği iddia edilebilir.

Katılımcılardan 0-36 yaş grubundaki çocuklarla çalışmayı, 36-72 ayık çocuklarla çalışmayla kıyaslamaları istendiğinde, katılımcılardan sadece \%10’u bebeklik dönemindeki çocuklarla çalışmanın avantajlarından bahsetmiştir. Bu avantajlar teknik, gelişimsel ve duygusal avantajlar olarak üç kategoride toplanmıştır. Teknik avantajlar kategorisinde katılımcılar, eğitim içeriğinin daha basit olması, çocukların öğrenebilecekleri çok daha fazla kavram olması, etkinliklerin kısa ve basit olması, yetişkin/çocuk oranının azlığından ve yaş grubunun küçük olmasından dolayı sınıf hakimiyetinin kolay sağlanması gibi durumları avantaj olarak belirtmişlerdir. Ortaya çıkan bu kategori çok düşük oranda olmasına rağmen, 0-36 aylık çocuklarla çalışmayı avantajlı bulan ögretmen adaylarının, ebeveynler ve toplum tarafindan yaygın olarak benimsenen ve bebeklik 
döneminin sadece fiziksel ve duygusal bakım gerektirdiğine vurgu yapan görüşten (Brownlee ve diğerleri, 2007) uzaklaştığını, entelektüel gelişiminde önemli olduğunu düşündügünü ortaya ç1karmıştır.

$\mathrm{Bu}$ soruya verilen yanıtlardan ortaya çıan temalar ve kategoriler incelendiğinde, öğretmen adaylarının bu yaş grubunun özelliklerini bildiği ancak bu yaş grubunun eğitimine yönelik teknik bilgiye yeterince sahip olmadıkları anlaşılmaktadır. Hem avantajlardan bahsederken hem de dezavantajlardan bahsederken, öğretmen adaylarının bebeklik dönemi eğitiminde olması gereken yetişkin/çocuk oranına, eğitim programına teknik açıdan yaklaşmadığı, varsayımlar üzerinden fikir yürüttükleri gözlemlenmiştir. Örneğin, her ikisi de 2013 yllında güncellenmiş olan 0-36 aylık çocuklar için eğitim programı ve Okul Öncesi Eğitim Programı (MEB, 2013) sarmal yapıdadır ve ulaşılamamış gelişim göstergeleri ya da kazanımların tekrar ele alınabileceğini öngörür. Ancak Tablo 4’te de görüldüğgü üzere, bu durum 0-36 aylık bebeklerle çalışmanın bir dezavantajı olarak görülmektedir. Yine benzer bir şekilde, eğitimci adaylarının 0-36 aylık çocuklarla "akademik etkinlik" yapılamayacağına dair bir inanışı vardır. Diğer taraftan, bebeklik dönemindeki çocukların öğrenebileceği çok daha fazla kavram olması, öğretmen adayları tarafindan bir avantaj olarak görülmektedir. Bu bulgu, bir taraftan olumlu bir taraftan ise olumsuz değerlendirilebilecek bir bulgudur. Daha öncede söylendiği gibi, bir taraftan bu bulgu öğretmen adaylarının bebeklik döneminde eğitime ilişkin fiziksel ve duygusal bakım odaklı düşünmediğinin göstergesidir. Ancak diğer taraftan, yine aynı bulgu bize öğretmen adaylarının ancak entellektüel etkinlikler gerçekleştirdiklerinde kendilerini bir öğretmen, eğitimci gibi hissedeceklerini göstermektedir. Oysa, bakımsal süreçler genelde erken çocukluk dönemi, özelde ise bebeklik dönemi eğitiminin vazgeçilmez bir parçasıdır ve hatta en iyi eğitim firsatlarıdır (Greenman ve Stone,1996). Moss (2000) 'a göre, okul öncesi öğretmenlerinin küçük çocuklara eğitim sunma konusundaki uygulama ve inançları, yeterlilik düzeylerinden ve mesleki eğitimlerinin kalitesinden çok güçlü bir biçimde etkilenmektedir. Mevcut çalısmaya katılan öğretmen adaylarının üniversite eğitimini tamamlamak üzere oldukları düşünüldüğ̈̈nde, bebeklik döneminde eğitime ilişkin bu düşünceleri öğretmen yetiştirme programlarının kalitesini ciddiyetle sorgulamamız gerektiğini düşündürmektedir.

Çalışmanın gerçekleştirildiği, 2008 ve 2015 yılları arasında, 60-72 aylık çocukların zorunlu okul öncesi eğitime dahil olması, Okul Öncesi Eğitimi Güçlendirme Projesi ve bu proje kapsamında 036 aylık Çocuklar için Eğitim Programının oluşturulması gibi bebeklik döneminin önemine vurgu yapma ihtimali çok yüksek gelişmeler yaşanmıştır. Ancak 2008,2010,2012,2014 ve 2015 yıllarında toplanan veriler ayrı ayrı incelendiğinde bu gelişmelerin, okul öncesi öğretmen adaylarının 
görüşlerine yansımadığı fark edilmiştir. Örneğin, yapılan yıllar arası karşılaştırmada "Sizce 0-36 aylık çocuklar erken çocukluk eğitimine dahil olmalı mıdır?” sorusuna, katılımcıların verilerin toplandığ1 her yıl benzer oranlarda hayır cevabını verdiği hatta son yıllarda toplanan verilerde bu soruya hayır cevabı veren öğretmen adayı oranının önceki yıllara göre daha fazla olduğu gözlemlenmiştir. Bu durumun olası sebepleri, okul öncesi eğitime ilişkin sosyal politikaların hayata geçirilmemiş olması, Millî Eğitim Bakanlı̆̆ı'nın 36-66 aylık çocuklar için hedeflediği okullaşma oranına dahi ulaşılamamış olması; bebeklik döneminde eğitim veren özel kurumlara ilişkin sürecin belirsiz olması olabilir. Örneğin, 2008 yılında başlatılan ve 60-72 aylık çocukların zorunlu okul öncesi eğitim almasını öngören uygulama devam ettirilmemiştir. 2010 yılında güncellenen 0-36 aylık Çocuklar İçin Eğitim Programı'nın uygulamaya girip girmediği, nasıl uygulandığı gibi konulara dair herhangi bir bilgi mevcut değildir. Tüm bu durumlar, okul öncesi öğretmenliği programlarında 36-72 aylık çocukların eğitimine daha fazla odaklanılması geleneğinin devam etmesine sebep olmuş ve özellikle bebeklik döneminde eğitime ilişkin beklenilen etkinin yaratılmasını sekteye uğratmıştır.

Akman (2013) 0-36 aylık Çocuk için Eğitim Programının uygulanmasına ilişkin gerekli uygulamalardan bahsederken, lisans programlarının gözden geçirilmesi gerektiğine vurgu yapmıştır. Ne yazkk ki, 2018 yılına kadar okul öncesi öğretmenliği programlarında herhangi bir değişime gidilmemiştir. Ancak, öğretmen yetiştirme programlarında da bu sebepleri elimine edebilecek bir değişiklik yapılmamıştır.

Bu durum erken çocukluk dönemi alanına eğitimci yetiştiren üniversite programlarının misyonlarını tam olarak yerine getiremediklerinin bir göstergesi olarak kabul edilebilir. Üniversitelerde yer alan Okul Öncesi Öğretmenliği Ana Bilim Dalları, 0-72 aylık çocukların eğitiminden sorumlu bireyler yetiştirmekle yükümlüdür. Ancak, bu çalışmanın verilerinin gösterdiği gerçek, öğretmen yetiştirme programlarının öğretmen adaylarına sunduğu derslerin ve uygulama firsatlarının 36 aydan büyük çocuklara yönelik olduğudur. Bu da eğitimci adaylarının 0-36 aylık çocuklara yabancılaşmasını, bu dönemdeki çocuklarla iletişim kurma, onlara eğitim firsatları yaratma ve onların öğrenmelerine destek olma konusunda kendilerini yetersiz hissetmelerine neden olmaktadır. Daha önce de belirtildiği gibi hem uygulanan sosyal politikalar hem de toplumda yaygın olarak kabul gören okula başlama yaşının en erken 36 ay olması, öğretmen yetiştirme programlarının bu eksiği ile birleştiğinde, 0-36 aylık çocukların kaliteli öğretmenler tarafından kaliteli bir eğitim alma ihtimali neredeyse ortadan kalkmaktadır. Tüm bu koşulların sonucu ise, araştırmaya katılan öğretmen adaylarının son soruya verdiği yanıtta açıkça görülmektedir. Öğretmen adayları, ne yazık ki, 0-36 aylık çocuklarla çalışmanın 36-66 aylık çocuklarla çalışmaya oranla dezavantajlı bir durum olduğunu 
beyan etmişlerdir. Böyle düşünen eğitimci adaylarının yüzdesi neredeyse verilerin toplandığı her y1l \%86'nın üzerindedir. Çalışmada dezavantaj olarak belirtilen nedenler incelendiğinde ise, öğretmen adaylarının 0-36 aylık Çocuklar için Eğitim Programı, Aile ve Sosyal Politikalar Bakanlı̆̆ı'nın ilgili yönetmeliğinde sunulan teknik bilgilerden haberdar olmadığı, daha çok varsayımlar üzerinden değerlendirmeler yaptıkları gözlemlenmiştir.

\section{SONUÇ ve ÖNERİLER}

Sonuç olarak mevcut çalışma erken çocukluk dönemi eğitimci adaylarının 0-3 yaş döneminin önemine dair farkındalıklarının var olduğunu ancak çoğunun bu yaş grubu ile çalışmaya sıcak bakmadığını, kendilerini bu konuda yetersiz hissettiklerini ve 0-3 yaş döneminde öğretmen kimliklerini kullanamayacaklarına dair bir algıya sahip olduklarını ortaya koymuştur. Bu noktada, okul öncesi eğitimin toplumsal, gelişimsel ve evrensel amaçlarının gerçekleştirilmesi için devlet tarafından yapılandırılan ve uygulanan sosyal politikaların 0-36 aylık dönemde çocukların evde bakımını desteklemektense, özellikle çalışan annelerin çocuklarının kaliteli bir eğitimden geçmiş, bebeklerin gelişimsel ihtiyaçları konusunda bilgili ve duyarlı eğitimciler tarafından kurumlarda bakımını teşvik edecek şekilde yeniden düzenlenmesi gerektiği iddia edilebilir. Örneğin, ivedilikle 0-36 aylık çocuklara sunulan eğitim ve bakım hizmeti MEB sorumluluğunda yürütülmeli ve devlette çalışmak isteyen üniversite mezunu öğretmenlerin 0-3 yaş gruplarılyla çalışmaları teşvik edilmelidir. $\mathrm{Bu}$ yaş grubuna hizmet veren eğitim kurumlarının talep ettikleri ücretlerin birçok ailenin karşılayabileceği düzeyden çok daha yüksek olduğu düşünüldüğünde (Dünya Bankas1, 2015), politika yapıcıların ailelerin ekonomik yükünü azaltacak ya da kurumların fiyatlarını düşürecek sosyal politika uygulamaları planlanmalıdır. Böylelikle, hem bebeklik döneminde eğitimi yaygınlaştırarak başta kadın istihdamını arttıracak (AÇEVve ERG, 2016; Dünya Bankası, 2015), hem de bu alanda kaliteli eğitimcilere duyulan ihtiyacı daha çok arttırarak, üniversite mezunu bireylerin bu alanda çalışmalarını cesaretlendirici uygulamaların ortaya çımasına neden olabilecektir. - Benzer bir şekilde, toplumun sahip olduğu "erken çocukluk eğitimine en erken 3 yaşında başlanmalıdır” (ERG ve AÇEV, 2017) algısını değiştirmek ve özellikle dezavantajlı çocukların birçok kritik dönemi kapsayan ilk üç yaş aralığında kaliteli bir eğitim almasını sağlayarak çocuklar arasında firsat eşitliğini yaratacak sosyal politikalar yapılandırılmalı ve uygulanmalıdır.

Çalışmanın sonuçları sosyal politikaların yanı sıra, öğretmen yetiştirme programlarına ve akademisyenlere de çok önemli sorumluluklar düştüğünü açıkça ortaya koymuştur. . YÖK'ün (2018) güncellediği okul öncesi öğretmenliği lisans programı ile "bebeklik döneminde gelişim ve eğitim” zorunlu bir ders olmuştur. Bu, yeni mezun olacak eğitimci adaylarının bebeklik dönemine 
ilişkin algılarını ve bu dönemdeki çocuklarla çalısmaya yönelik inanışlarını olumlu yönde değiştirebilecek önemli bir adımdır. Önemli bir ilk adım olmasına karşın, bu dersin birinci sınıfta, yani öğretmen adaylarının henüz alana çok hâkim olmadığı bir dönemde verilmesi, dersin etkisinin azalmasına neden olabilir. Bu nedenle ilerleyen sınıf düzeylerinde de, tüm derslerin içeriğinde mümkün olduğunca bebeklik dönemine ilişkin bilgi ve uygulama süreci dahil edilmelidir. Ayrıca, ulaşılmak istenilen değişimlerin tek bir ders ile olmayacağı da açıtır. Bu nedenle, erken çocukluk dönemi eğitimcileri yetiştiren programların içeriğine bebeklik döneminde eğitime yönelik birçok zorunlu ve seçmeli ders ile en az bir kere olmak üzere öğretmen adaylarının 0-36 aylık çocuklarla bir araya gelebileceği uygulamalar eklenmelidir. Yapılan tüm çalışmalar, bebeklik döneminde eğitime yönelik akademik alanda gerçekleştirilen çalışmaların azlı̆̆ına vurgu yapmakta ve alandaki akademisyenlerinde bebeklik döneminde eğitime yeterince önem vermediğini ortaya koymaktadır (Aksoy ve Koran, 2016; Metin, Akbaş, Yıldız ve Özaydın,2017). Bu nedenle, akademisyenlerinde 0-36 aylık çocukların eğitimine ilişkin daha fazla çalışma yapmasının, bebeklik dönemi eğitime verilen önemin arttırılmasında faydalı olacağı düşünülmektedir.

\section{Çalışmanın Sınırlılıkları}

Mevcut çalışmada veriler uzun bir zaman diliminde görece geniş bir örneklemden toplanmış ve öğretmen adaylarının bebeklik döneminde eğitime yönelik algılarını betimlemiştir. Bu yönüyle önemli olan bu çalışmanın bazı sınırlılıkları mevcuttur. Bunlardan ilki, nitel olan bu çalışmanın genellenebilir sonuçlar ortaya çıkarmamış olmasıdır. Her ne kadar, nitel bir araştırma için geniş bir katılımcı kitlesine ulaşılmış olsa da, çalışmanın nitel araştırmaya dayanan deseni sonuçları genellemek için uygun değildir. Okul öncesi öğretmen adaylarının, bebeklik döneminde eğitime yönelik algılarını daha objektif bir şekilde ve daha geniş ölçeklerde değerlendirebilmek için gerekli bir ölçüm aracı ulusal alan yazınında mevcut değildir. Bu bağlamda, ölçek geliştirme çalışmalarının, bebeklik döneminde eğitimle ilgili çalışmaların ve alana yönelik ilginin artmasına yardımcı olacağı düşünülmektedir.

Çalışmanın temel amaçlarından biri okul öncesi öğretmen adaylarının, bebeklik döneminde eğitime ilişkin görüşlerini betimlemektir. Bu bağlamda, çalışmada yazılı görüşme formu kullanılmıştır. Bu durum ise, öğretmen adaylarından derinlemesine bilgi almayı engellemiştir. Gelecekte yapılacak çalışmalarda, yüz-yüze görüşmeler daha derinlemesine bilgi almak adına tercih edilebilir. Mevcut çalışma, lisans eğitiminin son yılında olan erken çocukluk dönemi eğitimci adayları ile gerçekleştirilmiştir. Programın olası etkisini incelemek, eğitimci adaylarının görüşlerinde gerçekleşebilecek değişiklikleri gözlemleyebilmek adına farklı sınıflarda okuyan eğitimci adayları ile 
kesitsel ya da bir eğitimci adayı grubu ile boylamsal çalışmalarda yapılabilir. Daha öncede belirtildiği üzere, güncellenen lisans programında "bebeklik döneminde gelişim ve eğitim” dersi zorunlu bir ders olarak yer almaktadır. Gelecekteki çalışmalar, böyle bir dersin eğitimci adaylarının bebeklik döneminde eğitime ilişkin algılarını nasıl değiştirdiğine odaklanabilir. Son olarak, bebeklik döneminde eğitim süreci arza göre şekillenecek süreçlerden biridir. Bu nedenle bu konuda anne va babaların düşünceleri, tercihleri, ihtiyaçları belirlenmelidir. Yapılacak gelecek çalışmalarda anne ve babaların, 0-36 aylık çocuklarının bakımı ve eğitiminde yaşadıkları sıkıntılar, bu dönemde eğitime yönelik bakış açıları, ihtiyaçları ve taleplerine de yer verilebilir.

\section{KAYNAKÇA}

AÇEV ve ERG (2016) Her çocuğa eşit firsat: Türkiye'de erken cocukluk eüitiminin durumu ve öneriler, 10.07.2018 tarihinde http://www.egitimreformugirisimi.org/wp content/uploads/2017/03/ERG HERKES-\%C4\%B0C\%C4\%B0N-ESITFIRSAT TURKIYEDE-ERKEN-COCUKLUK-EGITIMININ-DURUMU-VE ONERILER.web .pdf sitesinden erişilmiştir.

Ainsworth, M. D. S., Blehar, M. C., Waters, E. ve Wall, S. (1978). Patterns of attachment: A psychological study of the strange situation. Hillsdale, NJ: Lawrence Erlbaum Associates

Angus, J., ve Carroll-Lind, J. (2011). Through their lens: An inquiry into nonparental education and care of infants and toddlers. Wellington, New Zealand: Office of the Children's Commissioner.

Akman, B. (2013). Milli Ë̆itim Bakanlı̆̆ 0-36 Aylık Çocuklara Yönelik 2012 Programı ve Uygulamaya Dair Olmazsa Olmazlar, 18 Haziran 2013, Swiss Otel, Ankara.

Aksoy, A. B. ve Koran, N. (2016). Türkiye'de bebeklik dönemi ile ilgili yapılan araştırmaların analizi (2004-2014), Türkiye Sosyal Araștermalar Dergisi, 363-376.

Akturan, U. ve Esen, A. (2008). Fenomenoloji. T. Baş ve U. Akturan (Ed.) içinde Nitel araștırma yöntemleri (ss. 83-98). Ankara: Seçkin Yayıncılık.

ASPB (2015). Özel kreş ve gündüz bakımevleri ile özel çocuk kulüplerinin kuruluş ve işleyiş esasları hakkinda yönetmelik, Resmi Gazete. 10.08.2018 tarihinde http://www.resmigazete.gov.tr/eskiler/2015/04/20150430-4.htm sitesinden erişilmiştir.

Bayhan P.S. ve Artan, İ. (2004). Çocuk Gelişimi ve Eğitimi. İstanbul: Morpa Kültür Yayınları.

Bieth, K.,Penny, T., Bulman, K., Robinson, M. (2005). Children's Care, Learning and Development.Oxford: Heinmann Educational Publishers.

Burchinal, M. R., Cryer, D., Clifford, R. M., ve Howes, C. (2002). Caregiver training and classroom quality in child care centers. Applied Developmental Science, 6, 2-11. 
Burchinal, M. R., Roberts, J. E., Riggins, R., Zeisel, S. A., Neebe, E., ve Bryant, D. (2000). Relating quality of center-based child care to early cognitive and language development longitudinally. Child Development, 71, 339-357.

Brownlee, J. M., Berthelsen, D. C. and Segaran, N. (2007) Childcare workers' and centre directors' beliefs about infant childcare quality and professional training. Early Child Development and Care, 179(4). pp. 453-475.

Calkins, S. (2007). The emergence of self-regulation: Biological and behavioral control mechanisms supporting toddler competencies. In C. A. Brownell ve C. B. Kopp (Eds.), Transitions in early socioemotional development: The toddler years (pp. 261 284). New York: Guilford Press

Clarke-Stewart, K. A., Vandell, D. L., Burchinal, M., O'Brien, M., ve McCartney, K. (2002). Doregulable features of child-care homes affect children's development? Early Childhood Research Quarterly, 17(1), 52-86.

Chalke, J. (2013). Will the early years professional please stand up? Professionalism in the earlychildhood workforce in England. Contemporary Issues in Early Childhood, 14(3), 212- 222.

Chang-Kredl, S., ve Kingsley, S. (2014). Identity expectations in early childhood teacher education: Pre-service teachers' memories of prior experiences and reasons for entry into the profession. Teaching and Teacher Education, 43, 27-36.

Dalli, C., White, E., J., Rockel, J., Duhn, I., Buchanan, E., Davidson, S., .. Wang, B. (2011).Quality early childhood education for under-two-year-olds: What should it look like? A literature review. Wellington, New Zealand: Ministry of Education.

Damast, A.M., Tamis-LeMonda, C.S., ve Bornstein, M.H. (1996). Mother-childplay: sequential interactions and the relation between maternal beliefs and behaviors. Child Development, 67(4):1752-66.

Dünya Bankası (2015) Türkiye'de Çocuk Bakım Hiðmetlerinde Aræve Talep Durumu, $\quad 12.08 .2018$ tarihinde http://documents.worldbank.org/curated/en/690781468000932565/pdf/98884TURKI SH-WP-P146295-PUBLIC-Box393197B-Binder-TR.pdf adresinden erișilmiștir.

Edwards, C. P. ve Raikes, H.(2002). "Extending the Dance: Relationship-Based Approaches to Infant/Toddler Care and Education" Faculty Publications, Department of Child, Youth, and Family $\quad$ Studies. 16. 10.08.2018 tarihinde http://digitalcommons.unl.edu/famconfacpub/16 sitesinden erişilmiştir.

Egan, B. (2007). Constructing a professional identity: some preliminary findings from students of early years education. European Early Childhood Education Research Journal, 12(2), 21-32.

ERG ve AÇEV (2017). Türkiye'de Okul Öncesi Eğitime Katılım: Bilgi Notu, 12.08 .2018 tarihinde http://www.egitimreformugirisimi.org/yayin/turkiyede-erken-cocukluk bakimi-veokul-oncesi egitime-katilim/ sitesinden erişilmiştir.

Erikson, E. H. (1950). Childhood and society. New York, NY, US: W W Norton ve Co. 
Gibson, M. (2013). "I want to educate school-age children": producing early childhood teacher professional identities. Contemporary Issues in Early Childhood, 14(2), 127-137.

Greenman, J. ve Stonehouse, A. (1996). Prime times: A handbook for excellence in infant and toddler care. St. Paul, MN: Redleaf Press.

Howes, C., Whitebrook, M., ve Phillips, D. A. (1992). Teacher characteristics and effective teaching in child care: Findings from the National Child Care Staffing Study. Child ve Youth Care Forum, 21, 399-414

Karp, N. (2006). Designing models for professional development at the local, state and national In M. Zaslow ve I. Martinez-Beck. (Eds.) Critical issues in early childhood Professional development (pp. 225-230). Baltimore: Brookes.

Kreader, J., Ferguson, D., ve Lawrence, S. (2005). Infant and toddler child care quality. Research to Policy Connections, No. 2

MEB (2013) Okul Öncesi Eğitim Program, 10.08.2018 tarihinde https://tegm.meb.gov.tr/dosya/okuloncesi/ooproram.pdf sitesinden erişilmiştir.

MEB (2013) 0-36 Aylhk Cocuklar için Eğitim Program, $\quad 10.08 .2018$ tarihindehttps://tegm.meb.gov.tr/dosya/okuloncesi/0-36program.pdf sitesinden erişilmiştir.

Metin, Ş., Akbaş, U., Yıldız, H. ve Özaydın, L. (2017). Türkiye'de 0-3 Yaş Çocuklara Yönelik Gerçekleştirilen Lisansüstü Tez Çalışmalarının Gözden Geçirilmesi, Uluslararası Erkeen Cocukluk Eğitimi Çalısmalar Dergisi,2 (1), 39-59.

Metin-Orta, İ. ve Sümer, N. (2016). Anne duyarlığ1 ve erken dönem bağlanma-temelli ebeveynlik destek ve müdahale programları, Türk Psikoloji Yąlar,19 (38), 54-73.

Patton, M. Q. (2002). Qualitative Research ve Evaluation Methods. Thousand Oaks, CA Sage Publications.

Pearce, J., ve Morrison, C. (2011). Teacher identity and early career resilience: exploring the links. Australian Journal of Teacher Education, 36(1), 48- 59.

Phillips, D., Mekos, D., Scarr, S., McCartney, K., ve Abbott-Shim, M. (2000). Within and beyond the classroom door: Assessing quality in child care centers. Early Childhood Research Quarterly, 15(4), 475-496.http://dx.doi.org/10.1016/S0885 2006(01)00077-1

Piaget, J. (1952). The Origins of Intelligence in Children. New York, NY: W.W. Norton ve Co. https://doi.org/10.1037/11494-000.

Sandelowski, M. (2000). Focus on Research Methods, Whatever Happened to Qualitative Description?, Research in Nursing ve Health, 23, 334-340.

Shonkoff, J. P. ve Phillips, D.A. (2000). From Neurons to Neighborhoods: The Science of Early Childhood Development. Washington, DC: National Academy Press. 
Thomas, L. (2012). New possibilities in thinking, speaking and doing: early childhood teachers'professional identity constructions and ethics. Australian Journal of Teacher Education, 37(3), 87-95.

Whitebook, M. (2003). Early education quality: Higher teacher qualifications for better learning environments a review of the literature. Berkeley, CA: Center for the Study of Child Care Employment, Institute of Industrial Relations.

Woddy, D. (2007). Infancy and Toddlerhood, 23.01.2019 tarihinde https://www.corwin.com/sites/default/files/upm-binaries/16296 Chapter 3.pdf sitesinden erişilmiştir.

Yıldırım, A. ve Şimşek, H. (2005). Sosyal Bilimlerde Nitel Araștrma Yöntemleri (5. Baskı). Ankara: Seçkin Yayıncilık.

Zigler, E. F., Finn-Stevenson, M., ve Hall, N. W. (2002). Current perspectives in psychology. The first three years ve beyond: Brain development and social policy. New Haven, CT, US: Yale University Press. 